Supporting Information

\title{
Bismuth Atoms in Hydrocarbon Ligands: Bismepines as Rigid, Ditopic Arene Donors in Coordination Chemistry
}

Jacqueline Ramler, Leonie Wüst, Anna Rempel, Laura Wolz, and Crispin Lichtenberg*

\author{
Department of Inorganic Chemistry \\ Julius-Maximilians-University Würzburg \\ Am Hubland, 97074 Würzburg, Germany. \\ Email: crispin.lichtenberg@uni-wuerzburg.de
}

\section{Table of Contents}

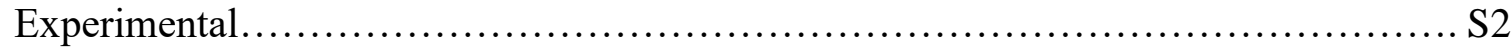

Single Crystal X-ray Diffraction Analysis......................................... S5

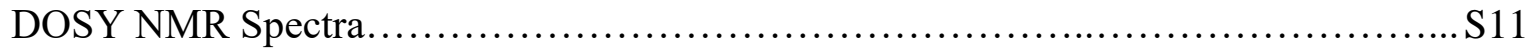

DFT Calculations........................................................... S13

Energies of Compounds Investigated by DFT Calculations......................... 15

NMR Spectra of Isolated Compounds..................................... S17

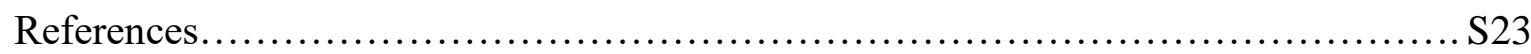




\section{Experimental}

General considerations. All air- and moisture-sensitive manipulations were carried out using standard vacuum line Schlenk techniques or in gloveboxes containing an atmosphere of purified argon. Solvents were degassed and purified according to standard laboratory procedures. NMR spectra were recorded on Bruker instruments operating at 400 or $500 \mathrm{MHz}$ with respect to ${ }^{1} \mathrm{H}$. ${ }^{1} \mathrm{H}$ and ${ }^{13} \mathrm{C}$ NMR chemical shifts are reported relative to $\mathrm{SiMe}_{4}$ using the residual ${ }^{1} \mathrm{H}$ and ${ }^{13} \mathrm{C}$ chemical shifts of the solvent as a secondary standard. ${ }^{11} \mathrm{~B}$ and ${ }^{19} \mathrm{~F}$ NMR chemical shifts are reported relative to $\mathrm{BF}_{3} \cdot \mathrm{OEt}_{2}$ and $\mathrm{CFCl}_{3}$ as external standards. NMR spectra were recorded at ambient temperature (typically $25{ }^{\circ} \mathrm{C}$ ), if not otherwise noted. Elemental analyses were performed on a Leco or a Carlo Erba instrument. Mass spectrometric analyses were performed with an Exactive Plus instrument (Thermo Scientific). Single crystals suitable for X-ray diffraction analysis were coated with polyisobutylene or perfluorinated polyether oil in a glovebox, transferred to a nylon loop and then to the goniometer of a diffractometer. The crystal data of $5\left[\mathbf{B A r F}{ }^{24}\right]$ and $\left.\left[\left(\left\{\mathbf{C}_{14} \mathbf{H}_{10}\right\} \mathbf{B i I}\right)\left(\mathbf{C}_{6} \mathbf{H}_{6}\right)_{2} \mathbf{T}\right]\right]\left[\mathbf{B A r F}^{24}\right]$ were collected on a Bruker D8 Quest diffractometer with a CCD-area detector and multi-layer mirror monochromated $\mathrm{MoK}_{\alpha}$ radiation $(\lambda=0.71073 \AA)$. The crystal data of $4\left[\mathbf{B A r}^{24}\right]$ were collected on a XtaLAB Synergy, Dualflex, Hypix diffractometer with a Hybrid Pixel Array detector and multi-layer mirror monochromated $\mathrm{CuK}_{\alpha}$ radiation $(\lambda=1.54184 \AA)$. The structures were solved using the intrinsic phasing method, refined with the SHELXL program, and expanded using Fourier techniques. ${ }^{1-3}$ All non-hydrogen atoms were refined anisotropically. Hydrogen atoms were included in structure factor calculations. All Hydrogen atoms were assigned to idealised positions. Crystallographic data have been deposited with the Cambridge Crystallographic Data Centre as supplementary publication number CCDC 2055286-2055288. These data can be obtained free of charge from The Cambridge Crystallographic Data Centre.

The following labeling scheme was used for reporting NMR chemical shifts:

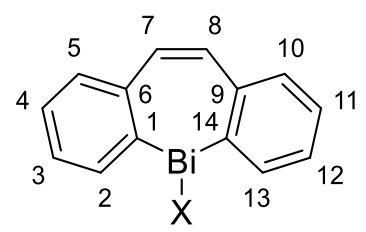

Compounds $\mathbf{2}$ and $\mathbf{3}$ were synthesized according to literature procedure. ${ }^{4}$ The ${ }^{13} \mathrm{C}$ NMR spectra of the compounds were recorded as part of this work.

\section{(Z)-1,2-Bis[2-(5H-dibenzo[b,f]bismepin-5-yl)phenyl]ethene (2)}

${ }^{13} \mathrm{C} \mathrm{NMR}\left(100 \mathrm{MHz}, \mathrm{CD}_{2} \mathrm{Cl}_{2}\right.$ ): $\delta=127.44$ (s, C-3, C-12), 128.57 (s, C-5 $\left.{ }^{\text {bridge }}, \mathrm{C}-10^{\text {bridge }}\right), 130.12$ (s, C-4 ${ }^{\text {bridge }}, \mathrm{C}-11^{\text {bridge }}$ ), 130.21 (s, C-2, C-13), 130.49 (s, C-4, C-11), 131.04 (s, C-3 ${ }^{\text {bridge }}$, C$12^{\text {bridge }}$ ), 133.37 (s, C-7, C-8), 136.10 (s, C-7 ${ }^{\text {bridge }}, \mathrm{C}^{\text {bridge }}$ ), 137.07 (s, C-5, C-10), 142.39 (s, C-2 $\left.2^{\text {bridge }}, \mathrm{C}-13^{\text {bridge }}\right), 142.63$ (s, C-6, C-9), 145.57 (s, C-6 ${ }^{\text {bridge }}, \mathrm{C}^{-9} 9^{\text {bridge }}$ ), 152.18 (s, C-1, C-14), 159.40 (s,C-1 ${ }^{\text {bridge }}, \mathrm{C}-14^{\text {bridge }}$ ) ppm. 


\section{5-Iodo-5H-dibenzo $[b, f]$ bismepine (3)}

${ }^{13} \mathrm{C}$ NMR (100 MHz, CD $\mathrm{Cl}_{2}$ ): $\delta=128.24$ (s, C-4, C-11), 131.39 (s, C-5, C-10), 132.53 (s, C7, C-8), 134.26 (s, C-3, C-12), 139.84 (s, C-2, C-13), 140.09 (s, C-6, C-9), 156.66 (br, C-1, C14) $\mathrm{ppm}$.

4[BArF ${ }^{24}$ ]. Neat Tl[BArF ${ }^{24}$ ] $(11.2 \mathrm{mg}, 10.5 \mu \mathrm{mol})$ was added to a solution of 2 (10.0 mg, 10.5 $\mu \mathrm{mol})$ in 1,2-difluorobenzene $(2 \mathrm{~mL})$. The suspension was filtered after $2 \mathrm{~h}$ at ambient temperature. The obtained colorless solution was layered with $n$-pentane $(2 \mathrm{~mL})$ and stored at $-30{ }^{\circ} \mathrm{C}$. After $2 \mathrm{~d}$ at $-30{ }^{\circ} \mathrm{C}$ the product could be obtained as a colorless crystalline solid. Yield: $20 \mathrm{mg}, 9.90 \mu \mathrm{mol}, 95 \%$.

${ }^{1} \mathbf{H}$ NMR $\left(400 \mathrm{MHz}, \mathrm{CD}_{2} \mathrm{Cl}_{2}\right): \delta=6.90$ (s, 4H, H-7, H-8), $7.17-7.25\left(8 \mathrm{H}, \mathrm{H}-7^{\text {bridge }}, \mathrm{H}-8^{\text {bridge }}\right.$, $\mathrm{H}-3^{\text {bridge }}, \mathrm{H}-12^{\text {bridge }}, \mathrm{H}-4, \mathrm{H}-11$ ), 7.27 - 7.31 (m, 8H, H-5, H-10, H-3, H-12), 7.37 - 7.43 (m, $\left.8 \mathrm{H}, \mathrm{H}-2, \mathrm{H}-13, \mathrm{H}-4^{\text {bridge }}, \mathrm{H}-11^{\text {bridge }}, \mathrm{H}-5^{\text {bridge }}, \mathrm{H}-10^{\text {bridge }}\right), 7.57$ (br, $4 \mathrm{H}$, para $\left.-\mathrm{C}_{6} \mathrm{H}_{3}\left(\mathrm{CF}_{3}\right)_{2}\right), 7.69$ $\left(\mathrm{d}, 2 \mathrm{H},{ }^{3} J_{\mathrm{HH}}=7.5 \mathrm{~Hz}, \mathrm{H}-2^{\text {bridge }}, \mathrm{H}-13^{\text {bridge }}\right), 7.73$ (br, $8 \mathrm{H}$, ortho- $\left.\mathrm{C}_{6} \mathrm{H}_{3}\left(\mathrm{CF}_{3}\right)_{2}\right)$ ppm.

${ }^{1} \mathbf{H}$ NMR $\left(500 \mathrm{MHz}\right.$ THF- $\left.d_{8}\right): \delta=6.77\left(\mathrm{~s}, 4 \mathrm{H}, \mathrm{C}_{2} \mathrm{H}_{2}\right), 7.01\left(\mathrm{ddd}, 4 \mathrm{H},{ }^{3} J_{\mathrm{HH}}=7.5 \mathrm{~Hz},{ }^{3} J_{\mathrm{HH}}=\right.$ $\left.7.3 \mathrm{~Hz},{ }^{4} \mathrm{~J}_{\mathrm{HH}}=1.3 \mathrm{~Hz}, \mathrm{C}_{6} \mathrm{H}_{4}\right), 7.08-7.20\left(\mathrm{~m}, 12 \mathrm{H}, \mathrm{C}_{6} \mathrm{H}_{4}\right), 7.25-7.38\left(\mathrm{~m}, 8 \mathrm{H}, \mathrm{C}_{6} \mathrm{H}_{4}\right), 7.56(\mathrm{~s}$, $4 \mathrm{H}$, para- $\left.\mathrm{C}_{6} \mathrm{H}_{3}\left(\mathrm{CF}_{3}\right)_{2}\right), 7.78\left(\mathrm{~s}, 8 \mathrm{H}\right.$, ortho $\left.-\mathrm{C}_{6} \mathrm{H}_{3}\left(\mathrm{CF}_{3}\right)_{2}\right), 7.83\left(\mathrm{~d}, 2 \mathrm{H},{ }^{3} J_{\mathrm{HH}}=7.5 \mathrm{~Hz}, \mathrm{C}_{6} \mathrm{H}_{4}\right) \mathrm{ppm}$.

${ }^{11} \mathbf{B}$ NMR $\left(128 \mathrm{MHz}, \mathrm{CD}_{2} \mathrm{Cl}_{2}\right): \delta=-6.61\left(\mathrm{~s}, \mathrm{~B}\left(\mathrm{C}_{6} \mathrm{H}_{3}\left(\mathrm{CF}_{3}\right)_{2}\right)_{4}{ }^{-}\right) \mathrm{ppm}$.

${ }^{13} \mathrm{C}$ NMR (100 MHz, $\left.\mathrm{CD}_{2} \mathrm{Cl}_{2}\right): \delta=117.92\left(\mathrm{~m}\right.$, para $\left.-\mathrm{C}_{6} \mathrm{H}_{3}\left(\mathrm{CF}_{3}\right)_{2}\right), 123.63$ (q, ${ }^{3} J_{\mathrm{CF}}=272.4 \mathrm{~Hz}$, $\mathrm{CF}_{3}$ ), 129.29 (quartquart, ${ }^{2} J_{\mathrm{CF}}=28.89 \mathrm{~Hz},{ }^{4} J_{\mathrm{CF}}=2.6 \mathrm{~Hz}$, meta- $\left(3,5-\mathrm{C}_{6} \mathrm{H}_{3}\left(\mathrm{CF}_{3}\right)_{2}\right), 128.37(\mathrm{~s}, \mathrm{C}-$ 3, C-12), 129.22 (s, C-5 ${ }^{\text {bridge }}, \mathrm{C}-10^{\text {bridge }}$ ), 131.07 (s, C-4 $\left.{ }^{\text {bridge }}, \mathrm{C}-11^{\text {bridge }}\right), 131.18$ (s, C-2, C-13), 131.28 (s, C-4, C-11), 132.69 (s, C-3 ${ }^{\text {bridge }}, \mathrm{C}-12^{\text {bridge }}$ ), 133.55 (s, C-7, C-8), 135.21 (br, s, ortho$\left.\mathrm{C}_{6} \mathrm{H}_{3}\left(\mathrm{CF}_{3}\right)_{2}\right)$ ), 136.10 (s, C-7 $\left.{ }^{\text {bridge }}, \mathrm{C}-8^{\text {bridge }}\right), 137.46$ (s, C-5, C-10), 141.52 (s, C-2 ${ }^{\text {bridge }}, \mathrm{C}-$ $13^{\text {bridge }}$ ), 142.53 (s, C-6, C-9), 145.65 (s, C-6 $\left.{ }^{\text {bridge }}, \mathrm{C}^{-9^{\text {bridge }}}\right), 154.20$ (s, C-1, C-14), 157.87 (s, C$\left.1^{\text {bridge }}, \mathrm{C}-14^{\text {bridge }}\right), 162.2\left(\mathrm{q},{ }^{1} J_{\mathrm{BC}}=50.8 \mathrm{~Hz}\right.$, ipso- $\left.\mathrm{C}_{6} \mathrm{H}_{3}\left(\mathrm{CF}_{3}\right)_{2}\right) \mathrm{ppm}$.

${ }^{19}$ F NMR $\left(376 \mathrm{MHz}, \mathrm{CD}_{2} \mathrm{Cl}_{2}\right): \delta=-62.82\left(\mathrm{~s}, \mathrm{CF}_{3}\right) \mathrm{ppm}$.

Elemental analysis: Anal. calc. for: $\mathrm{C}_{74} \mathrm{H}_{42} \mathrm{Bi}_{2} \mathrm{TlBF}_{24}\left(2020.24 \mathrm{~g} \cdot \mathrm{mol}^{-1}\right)$ : C 43.99, H 2.10; found: C 44.11, H 1.92 .

ESI-MS: positive mode (\%), calculated for $\left[\mathrm{C}_{42} \mathrm{H}_{30} \mathrm{Bi}_{2} \mathrm{Tl}\right]^{+}, \mathrm{m} / \mathrm{z}=1157.1694$; found: 1157.1676 (100). 
$\mathbf{5}\left[\mathbf{B A r F}^{24}\right]$. Neat compound $\mathbf{3}(9.6 \mathrm{mg}, 18.7 \mu \mathrm{mol})$ was added to a solution of Tl[BArF $\left.{ }^{24}\right](10.0$ $\mathrm{mg}, 9.36 \mu \mathrm{mol})$ in 1,2-difluorobenzene $(1 \mathrm{~mL})$. The suspension was filtered after $3 \mathrm{~h}$ at ambient temperature. The obtained light yellow solution was layered with $n$-pentane $(1 \mathrm{~mL})$ and stored at $-30{ }^{\circ} \mathrm{C}$. After $3 \mathrm{~d}$ at $-30{ }^{\circ} \mathrm{C}$ the product could be obtained as a colorless crystalline solid. Yield: $19.5 \mathrm{mg}, 9.30 \mu \mathrm{mol}, 99 \%$.

${ }^{1} \mathbf{H}$ NMR $\left(500 \mathrm{MHz}, \mathrm{CD}_{2} \mathrm{Cl}_{2}\right): \delta=7.17(\mathrm{~s}, 4 \mathrm{H}, \mathrm{H}-7 / \mathrm{H}-8), 7.45\left(\mathrm{ddd}, 4 \mathrm{H},{ }^{3} J_{\mathrm{HH}}=7.5 \mathrm{~Hz},{ }^{3} J_{\mathrm{HH}}=\right.$ $\left.7.5 \mathrm{~Hz},{ }^{4} J_{\mathrm{HH}}=1.2 \mathrm{~Hz}, \mathrm{H}-4 / \mathrm{H}-11\right), 7.53\left(\mathrm{dd}, 4 \mathrm{H},{ }^{3} J_{\mathrm{HH}}=7.7 \mathrm{~Hz},{ }^{4} J_{\mathrm{HH}}=1.2 \mathrm{~Hz}, \mathrm{H}-5 / \mathrm{H}-10\right), 7.56$ (s, $4 \mathrm{H}$, para- $\left.\mathrm{C}_{6} \mathrm{H}_{3}\left(\mathrm{CF}_{3}\right)_{2}\right), 7.61\left(\mathrm{ddd}, 4 \mathrm{H},{ }^{3} J_{\mathrm{HH}}=7.4 \mathrm{~Hz},{ }^{3} J_{\mathrm{HH}}=7.4 \mathrm{~Hz},{ }^{4} J_{\mathrm{HH}}=1.2 \mathrm{~Hz}, \mathrm{H}-3 / \mathrm{H}-\right.$ 12), 7.72 (s, 8H, ortho- $\left.\mathrm{C}_{6} \mathrm{H}_{3}\left(\mathrm{CF}_{3}\right)_{2}\right), 9.12\left(\mathrm{~d}, 4 \mathrm{H},{ }^{3} J_{\mathrm{HH}}=7.6 \mathrm{~Hz}, \mathrm{H}-2 / \mathrm{H}-13\right) \mathrm{ppm}$.

${ }^{11} \mathbf{B}$ NMR $\left(128 \mathrm{MHz}, \mathrm{CD}_{2} \mathrm{Cl}_{2}\right): \delta=-6.60\left(\mathrm{~s}, \mathrm{~B}\left(\mathrm{C}_{6} \mathrm{H}_{3}\left(\mathrm{CF}_{3}\right)_{2}\right)_{4}{ }^{-}\right) \mathrm{ppm}$.

${ }^{13} \mathbf{C ~ N M R}\left(126 \mathrm{MHz}, \mathrm{CD}_{2} \mathrm{Cl}_{2}\right): \delta=117.89\left(\mathrm{~m}\right.$, para $\left.-\mathrm{C}_{6} \mathrm{H}_{3}\left(\mathrm{CF}_{3}\right)_{2}\right), 124.98$ (q, ${ }^{3} J_{\mathrm{CF}}=272.6 \mathrm{~Hz}$, $\mathrm{CF}_{3}$ ), 128.87 (quartquart, ${ }^{2} J_{\mathrm{CF}}=31.4 \mathrm{~Hz},{ }^{4} J_{\mathrm{CF}}=3.0 \mathrm{~Hz}$, meta- $\left(3,5-\mathrm{C}_{6} \mathrm{H}_{3}\left(\mathrm{CF}_{3}\right)_{2}\right) 129.44(\mathrm{~s}, \mathrm{C}-$ 4/C-11), 132.32 (s, C-5/C-10), 132.77 (s, C-7/C-8), 134.99 (s, C-3/C-12), 135.20 (br, s, ortho$\left.\mathrm{C}_{6} \mathrm{H}_{3}\left(\mathrm{CF}_{3}\right)_{2}\right), 140.68$ (s, C-2/C-13), 140.70 (s, C-6, C-9), 158.74 (s, C-1/C-14), 162.15 (q, ${ }^{2} J_{\mathrm{BC}}$ $=49.7 \mathrm{~Hz}$, ipso- $\left.\mathrm{C}_{6} \mathrm{H}_{3}\left(\mathrm{CF}_{3}\right)_{2}\right) \mathrm{ppm}$.

${ }^{19}$ F NMR $\left(470 \mathrm{MHz}, \mathrm{CD}_{2} \mathrm{Cl}_{2}\right): \delta=-62.8\left(\mathrm{~s}, \mathrm{CF}_{3}\right) \mathrm{ppm}$.

Elemental analysis: Anal. calc. for: $\mathrm{C}_{60} \mathrm{H}_{32} \mathrm{Bi}_{2} \mathrm{TlBI}_{2} \mathrm{~F}_{24}\left(2095.84 \mathrm{~g} \cdot \mathrm{mol}^{-1}\right)$ : C 34.39, H 1.54; found: C 34.62, H 1.48 .

ESI-MS: positive mode $(\%)$, calculated for $\left[\mathrm{C}_{14} \mathrm{H}_{10} \mathrm{BiITl}\right]^{+}, \mathrm{m} / \mathrm{z}=718.9375$; found: 718.9366 (65). 


\section{Single Crystal X-ray Diffraction Analysis}

Crystal structure of $4\left[\mathbf{B A r F} \mathbf{F}^{24}\right]$. The displacement parameters of atoms C49_4 and C49_5 were constrained to the same value with the EADP keyword. The displacement parameters of atoms C66_6 and C66_7 were constrained to the same value with the EADP keyword. The atomic displacement parameters of all atoms of the residues 1,2-difluorobenzene and $\mathrm{CF}_{3}$ were restrained with the RIGU keyword in the ShelXL input ('enhanced rigid bond' restraint for all bonds in the connectivity list. Standard values of 0.004 for both parameters s1 and s2 were used). The displacement parameters of all atoms of the residues $\mathrm{CF}_{3}$ and 1,2-difluorobenzene were restrained to the same value with the similarity restraint SIMU. The $\mathrm{U}_{\mathrm{ii}}$ displacement parameters of all atoms of the residues $\mathrm{CF}_{3}$ and 1,2-difluorobenzene were restrained with the ISOR keyword to approximate isotropic behavior.

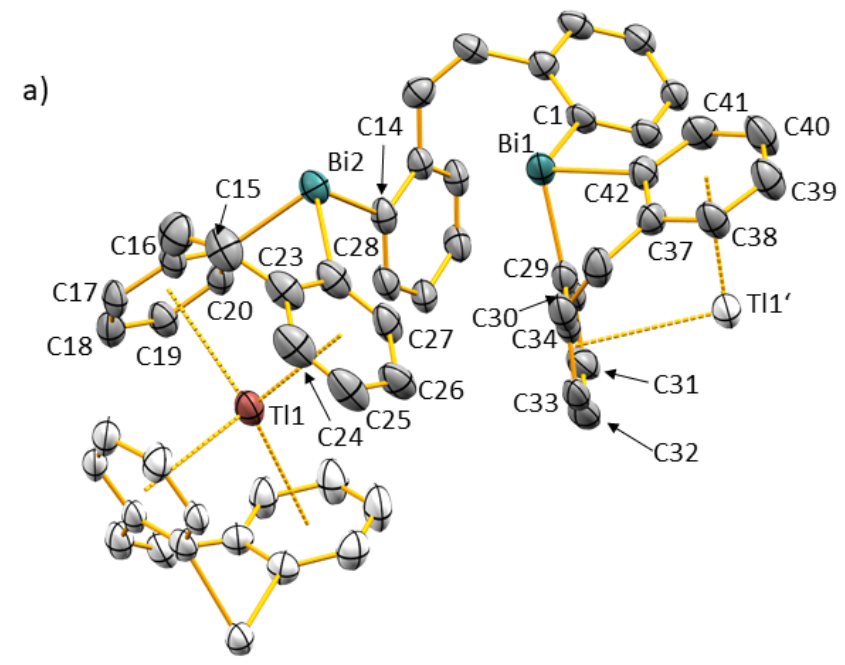

b)

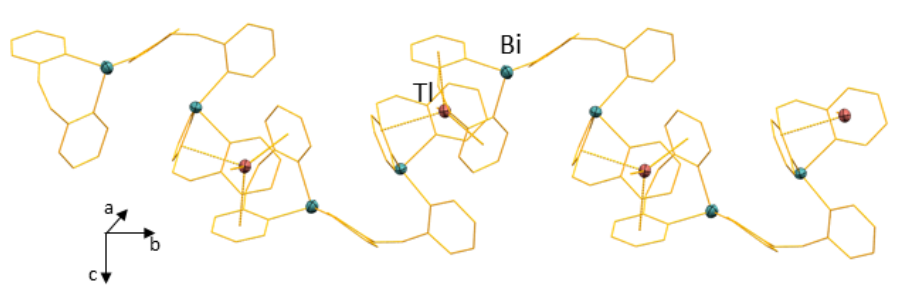

Figure S1. a) Cutout of the solid-state structure of coordination polymer $4\left[\mathbf{B A r F} \mathbf{F}^{24}\right]$. Displacement ellipsoids are shown at the $50 \%$ probability level. Hydrogen atoms, the counterion and lattice-bound 1,2-difluorobenzene molecules are omitted for clarity. Atoms exceeding one formula unit are shown as white ellipsoids. b) Representation showing the arrangement of $\mathbf{4}\left[\mathbf{B A r F}^{\mathbf{2 4}}\right]$ as a one-dimensional coordination polymer in the solid state. Selected bond lengths $(\AA)$ and angles $\left({ }^{\circ}\right)$ : Bi1-C1, 2.255(9); Bi1-C29, 2.277(11); Bi1-C42, 2.264(9); Bi2-C14, 2.246(10); Bi2-C15, 2.250(9); Bi2-C28, 2.252(11); T11‥ct1, 3.073;

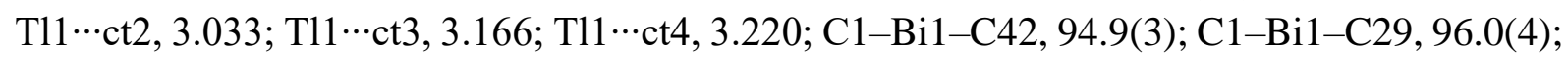
C42-Bi1-C29, 85.1(4); C14-Bi2-C15, 95.1(3); C14-Bi2-C28, 97.8(4); C15-Bi2-C28,

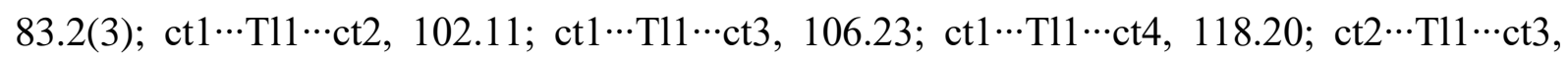

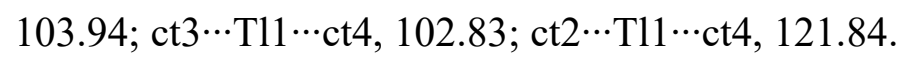


Crystal structure of $\mathbf{5}\left[\mathbf{B A r F} \mathbf{F}^{\mathbf{2 4}}\right]$. As described in the main text, $\mathbf{5}\left[\mathbf{B A r} \mathbf{F}^{\mathbf{2 4}}\right]$ crystallizes with two chemical identical, but crystallographic independent molecules in the unit cell. One molecule was depicted in the main part (also see Figure S2). The second molecule is depicted in Figure S3. The thallium cation is also coordinated by four arene moieties of two bismepine units with bond lengths and -angles in the same range as those of the structure shown in the main part $\left(2.99-3.25 \AA ; 100.48-118.77^{\circ}\right)$. The bismuth atoms Bi3 and Bi4 show a trigonalpyramidal coordination without major differences compared to thallium-free starting material 3. Weak interactions between Bi3 and F44 are present based on distance criteria (Bi3 $\cdots \mathrm{F} 443.29$ $\AA$, $7 \%$ below the sum of the Van-der-Waals radii of $3.54 \AA$ ).

The displacement parameters of atoms C120_4 and C120_5, as well as C36_10 and C36_11 and C69_12 and C69_13 were each constrained to the same value with the EADP keyword. The coordinates of atoms C36_10 and C36_11 were constrained to the same value. The atomic displacement parameters of atoms of $\mathrm{CF}_{3}$-groups were restraint with the RIGU keyword in the ShelXL input ('enhanced rigid bond' restraint for all bonds in the connectivity list. Standard values of 0.004 for both parameters $\mathrm{s} 1$ and s2 were used). The displacement parameters of all atoms of $\mathrm{CF}_{3}$-groups were restrained to the same value with the similarity restraint SIMU. The 1-2 and 1-3 distances in residues 10 and $11\left(\mathrm{CF}_{3}\right), 1,2$ and $3\left(\mathrm{CF}_{3}\right)$ were restrained to the same values with the SAME keyword. The $\mathrm{U}_{\mathrm{ii}}$ displacement parameters of all atoms of $\mathrm{CF}_{3}$-groups were restrained with the ISOR keyword to approximate isotropic behavior. Two bismepine units are disordered and their geometry was idealized based on non-disordered bismepine geometries available in the unit cell. Although several different crystals were measured, the result could not be improved due to insufficient scattering. 


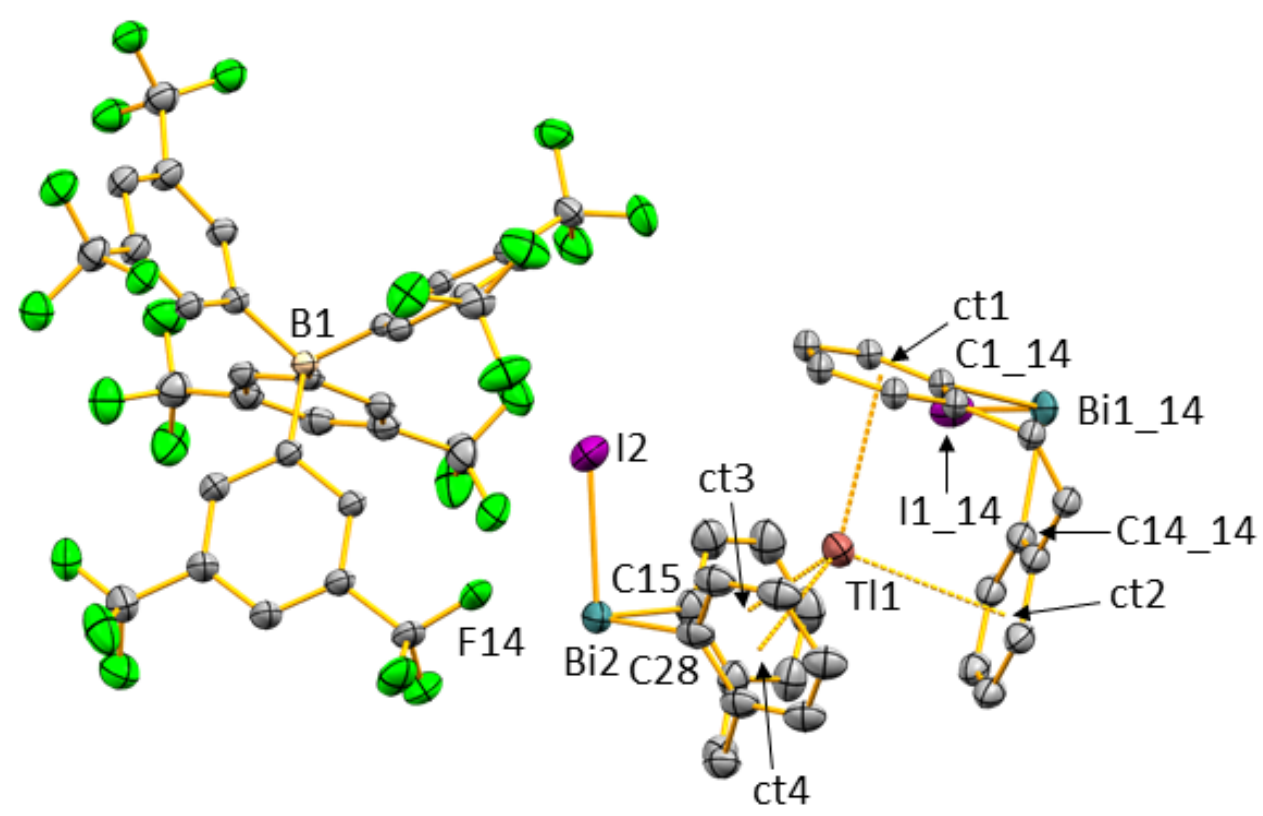

Figure S2. Molecular structure of $\mathbf{5}\left[\mathbf{B A r} \mathbf{F}^{24}\right]$ in the solid state. The asymmetric unit contains two chemically identical but crystallographically independent formula units of $\mathbf{5}\left[\mathbf{B A r F}^{\mathbf{2 4}}\right.$ ], only one of which is discussed because the bonding parameters do not differ significantly (see below). Displacement ellipsoids are shown at the 50\% probability level. Hydrogen atoms and split positions are omitted for clarity; ct1 represents the centroid of $C\left(1 \_14-6 \_14\right)$, ct2 represents the centroid of $\mathrm{C}\left(9 \_14-14 \_14\right)$, ct3 represents the centroid of $\mathrm{C}(15-20)$ and ct4 represents the centroid of $\mathrm{C}(23-28)$. Selected bond lengths $(\AA)$ and bond angles $\left({ }^{\circ}\right)$ : Bi1_14C1_14, 2.257(14); Bi1_14-C14_14, 2.291(14); Bi1_14-I1_14, 2.758(7); Bi2-C15, 2.254(11);

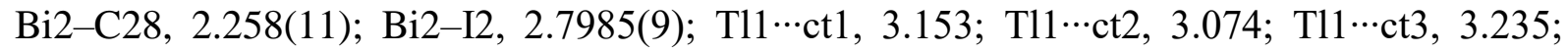
T11‥ct4, 3.058; C1_14-Bi1_14-C14_14, 84.6(8); I1_14-Bi1_14-C1_14, 95.4(5); I1_14Bi1_14-C14_14, 94.2(6); C15-Bi2-C28, 87.0(4); I2-Bi2-C15, 95.2(3); I2-Bi2-C28, 92.1(3);

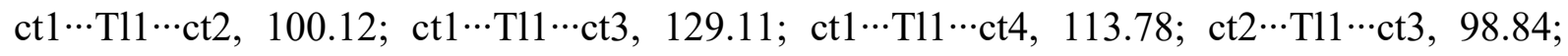

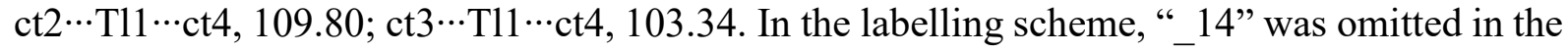
main part for clarity. 


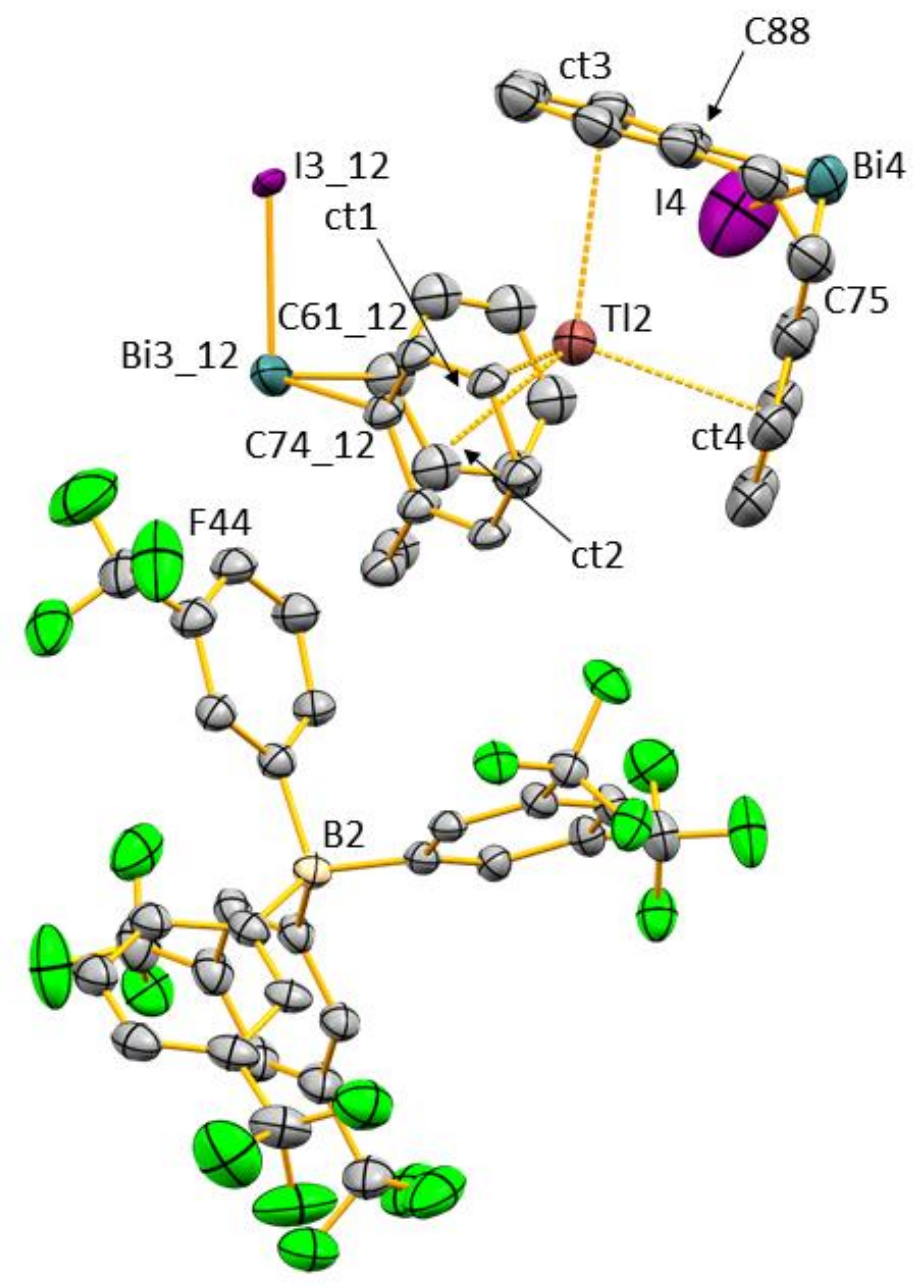

Figure S3. Molecular structure of $\mathbf{5}\left[\mathbf{B} \mathbf{A r} \mathbf{F}^{24}\right]$ in the solid state. Displacement ellipsoids are shown at the $50 \%$ probability level. Hydrogen atoms and split positions are omitted for clarity; ct1 represents the centroid of $\mathrm{C}\left(61 \_12-66 \_12\right)$, ct2 represents the centroid of C(69_12-74_12), ct3 represents the centroid of $\mathrm{C}(75-80)$ and ct 4 represents the centroid of $\mathrm{C}(83-88)$. Selected bond lengths $(\AA)$ and bond angles $\left(^{\circ}\right)$ : Bi3_12-C61_12, 2.22(3); Bi3_12-C74_12, 2.26(2); Bi3_12-I3_12, 2.763(5); Bi4-C75, 2.258(12); Bi4-C88, 2.264(13); Bi4-I4, 2.7223(16);

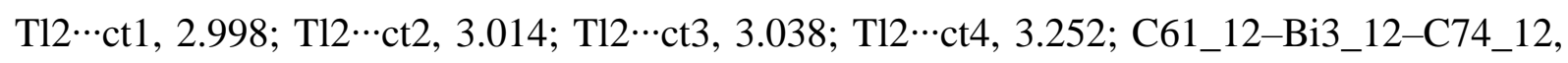
84.9(8); I3_12-Bi3_12-C61_12, 97.4(7); I3_12-Bi3_12-C74_12, 96.7(5); C75-Bi4-C88,

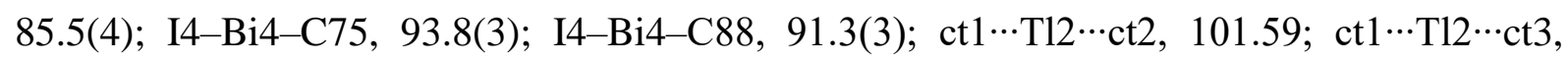
118.77 ; ct $1 \cdots \mathrm{T} 12 \cdots \mathrm{ct} 4,117.50 ;$ ct $2 \cdots \mathrm{T} 12 \cdots$ ct $3,108.42 ;$ ct $2 \cdots \mathrm{T} 12 \cdots \operatorname{ct} 4,111.94 ;$ ct $3 \cdots \mathrm{T} 12 \cdots \operatorname{ct} 4$, 100.48 . 
Table S1. Comparison of structural parameters in 2, 3, 4[BArF $\left.{ }^{24}\right]$, and $5\left[\mathrm{BArF}^{24}\right]$.

\begin{tabular}{|c|c|c|c|c|}
\hline & 2 & 3 & $4\left[\mathrm{BArF}^{24}\right]$ & $5\left[\mathrm{BArF}^{24}\right]$ \\
\hline $\mathrm{Bi}-\mathrm{C}[\AA]$ & $2.24-2.26$ & $2.24-2.25$ & $2.25-2.28$ & $2.25-2.29$ \\
\hline $\mathrm{Bi}-\mathrm{X}[\AA]^{\mathrm{a}}$ & 2.26 & 2.79 & $2.25-2.26$ & $2.76-2.80$ \\
\hline$\Varangle(\mathrm{C}-\mathrm{Bi}-\mathrm{C})\left[{ }^{\circ}\right]^{\mathrm{b}}$ & $88.3-88.8$ & 85.7 & $83.2-85.1$ & $85.9-87.0$ \\
\hline$\Varangle($ benzo/benzo $)\left[{ }^{\circ}\right]^{b}$ & $106.4-107.3$ & 88.7 & $90.4-100.9$ & $84.1-89.0$ \\
\hline
\end{tabular}

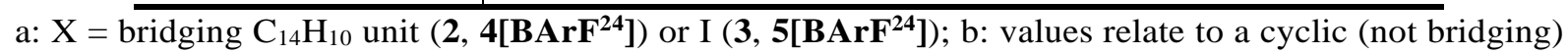
$\mathrm{BiC}_{14} \mathrm{H}_{10}$ unit.

Crystal structure of $\left[\left(\left\{\mathbf{C}_{14} \mathbf{H}_{10}\right\} \mathbf{B i I}\right)\left(\mathbf{C}_{6} \mathbf{H}_{6}\right)_{2} \mathbf{T l}\right]\left[B \mathbf{B A r F}^{24}\right]$. When small amounts of benzene were present during the synthesis of $\mathbf{5}\left[\mathbf{B} \mathbf{A} \mathbf{r F}^{24}\right]$ small amounts of the mixed adduct $\left[\left(\left\{\mathrm{C}_{14} \mathrm{H}_{10}\right\} \mathrm{BiI}\right)\left(\mathrm{C}_{6} \mathrm{H}_{6}\right)_{2} \mathrm{Tl}\right]\left[\mathrm{BArF}{ }^{24}\right]$ were obtained (triclinic space group $P \overline{1}$ with $Z=2$; Figure S4). The thallium atom T11 is coordinated by four arene-moieties with bond angles of ct $1 \cdots$ T11 $\cdots$ ct $297.77^{\circ}$, ct $1 \cdots$ T11 $\cdots$ ct3 $120.45^{\circ}$, and ct $1 \cdots$ T11 $\cdots$ ct $4108.24^{\circ}$ resulting in a distorted tetrahedral coordination geometry. In comparison to $\mathbf{4}\left[\mathbf{B A} \mathbf{A} \mathbf{F}^{24}\right]$ and $\mathbf{5}[\mathbf{B A r F}]$ the distortion of the ideal tetrahedral geometry is less pronounced, which can be ascribed to the higher flexibility of the benzene ligands. The distances between T11 and the centroids of the arene rings are 3.084 $\AA$, $3.098 \AA$, $3.041 \AA$ and $3.319 \AA$ and in the same range as for compounds $\mathbf{4}\left[\mathbf{B A r} \mathbf{F}^{\mathbf{2 4}}\right]$ and $\mathbf{5}\left[\mathbf{B A r F}^{24}\right]$. It must be pointed out that the unusual tetra-arene coordination of the thallium atom is maintained, although two monotopic arene ligands are present. The bismuth atom Bi1 adopts a trigonal-pyramidal geometry with no significant modifications in bond lengths and -angles in comparison to starting material 3.

The atomic displacement parameters of all atoms of the residues 4 and 5 were restrained with the RIGU keyword in the ShelXL input ('enhanced rigid bond' restraint for all bonds in the connectivity list. Values of 0.003 for parameter s1 and 0.004 for parameter s2 were used). The displacement parameters of all atoms of the residues 4 and 5 were restrained to the same value with the similarity restraint SIMU. The $\mathrm{U}_{\mathrm{ii}}$ displacement parameters of all atoms of the residues 4 and 5 were restrained with the ISOR keyword to approximate isotropic behavior. The displacement parameters of atoms C56_1, C56_2, and C56_3 (of the residues 1, 2 and 3) were constrained to the same value with the EADP keyword. The coordinates of atoms C56_1, C56_2, and C56_3 were constrained to the same value. The atomic displacement parameters of atoms C27, C28, C29, C30, C31, C32 and C33 of the lattice-bound toluene molecule were restrained with the RIGU keyword in the ShelXL input ('enhanced rigid bond' restraint for all bonds in the connectivity list. Values of 0.01 for parameter $\mathrm{s} 1$ and 0.004 for parameter s 2 were used). The displacement parameters of atoms C27, C28, C29, C30, C31, C32 and C33 of the lattice-bound toluene molecule were restrained to the same value with the similarity restraint SIMU. The $U_{\text {ii }}$ displacement parameters of atoms of the lattice-bound toluene molecule were restrained with the ISOR keyword to approximate isotropic behavior. 


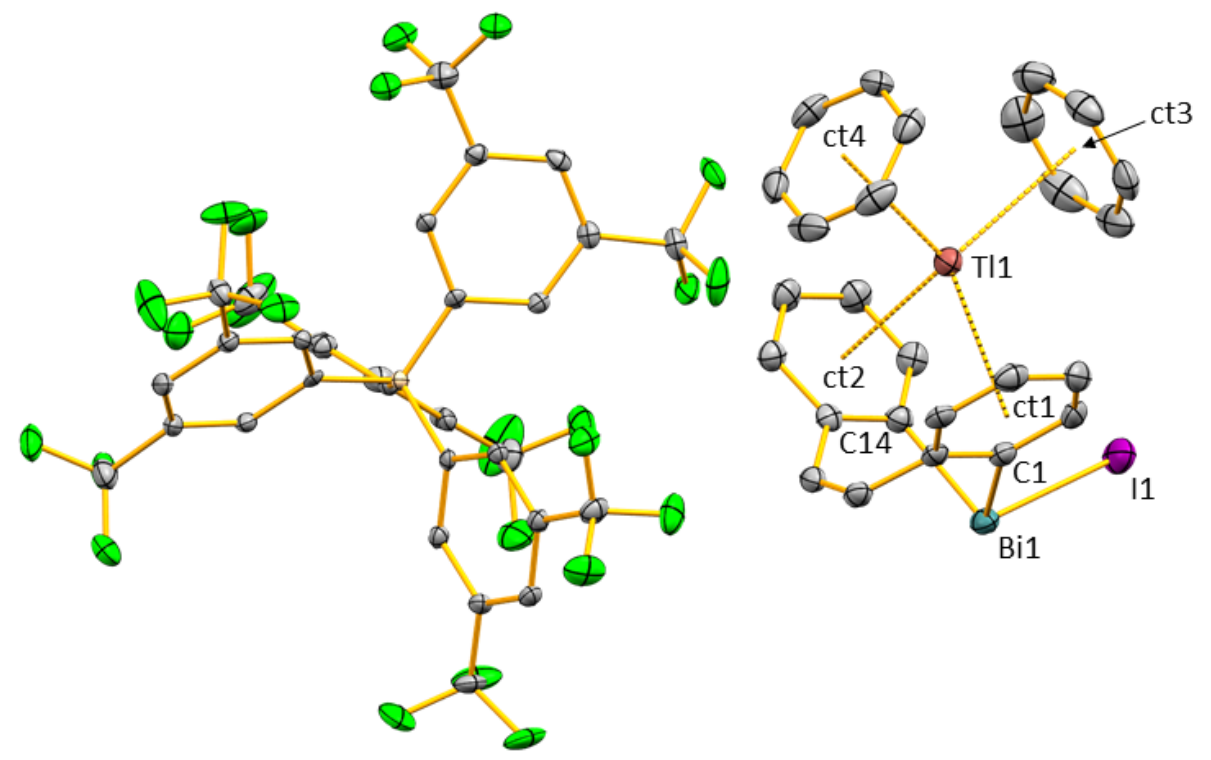

Figure S4. Molecular structure of $\left[\left(\left\{\mathrm{C}_{14} \mathrm{H}_{10}\right\} \mathrm{BiI}\right)\left(\mathrm{C}_{6} \mathrm{H}_{6}\right)_{2} \mathrm{Tl}\right]\left[\mathrm{BArF}^{24}\right]$ in the solid state. Displacement ellipsoids are shown at the 50\% probability level. Hydrogen atoms, split positions, and lattice-bound toluene are omitted for clarity; ct1 represents the centroid of C(1$6)$, ct2 represents the centroid of $\mathrm{C}(9-14)$, ct3 represents the centroid of $\mathrm{C}(15-20)$ and ct4 represents the centroid of $\mathrm{C}(21-26)$. Selected bond lengths $(\AA)$ and bond angles $\left({ }^{\circ}\right)$ : $\mathrm{Bi} 1-\mathrm{C} 1$,

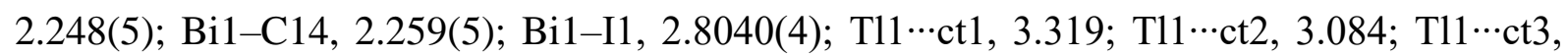
3.098; T11‥ct4, 3.041; C1-Bi1-C14, 84.96(18); I1-Bi1-C1, 96.45(13); I1-Bi1-C14, 95.85(13); ct $1 \cdots$ T11 $\cdots$ ct $2,97.77$; ct $1 \cdots$ T11 $\cdots$ ct $3,120.45$; ct $1 \cdots$ T11 $\cdots$ ct $4,108.24$; ct $2 \cdots$ T11 $\cdots$ ct3, 114.88 ; ct $2 \cdots$ T11 $\cdots$ ct $4,110.28$; $\operatorname{ct} 3 \cdots$ T11 $\cdots$ ct $4,106.69$. 


\section{DOSY NMR Experiments}

${ }^{1} \mathrm{H}$ DOSY NMR experiments were performed with solutions of $\mathbf{2 , 3}, \mathbf{4}\left[\mathbf{B A r F}^{\mathbf{2 4}}\right]$ and $\mathbf{5}\left[\mathbf{B} \mathbf{A r} \mathbf{F}^{24}\right]$ in $\mathrm{CD}_{2} \mathrm{Cl}_{2}$ and with solutions of $\mathbf{2}$ and $\mathbf{4}\left[\mathbf{B A r F}^{24}\right]$ in THF- $d_{8}$ on a Bruker Avance III Nanobay 400 NMR spectrometer with a LED pulse sequence with bipolar gradients and two spoil gradients (ledbpgp2s) using a standard $5 \mathrm{~mm}$ ATM BBO probe with z-gradient at $25{ }^{\circ} \mathrm{C}$. The ${ }^{1} \mathrm{H}$ frequency was $400.47 \mathrm{MHz}$. The temperature was calibrated using a sample of $4 \% \mathrm{MeOH}$ in MeOD- $d_{4}$ according to the literature. ${ }^{5}$ The gradient strength of the probe was calibrated using a "doped water" sample provided by Bruker $\left(\mathrm{Z} 10906 ; \mathrm{D}_{2} \mathrm{O}\right.$ with $0.1 \mathrm{mg} / \mathrm{mLGdCl}_{3}, 1 \% \mathrm{H}_{2} \mathrm{O}$, and $0.1 \%{ }^{13} \mathrm{CH}_{3} \mathrm{OH}$ at a filling height of $40 \mathrm{~mm}$ ). Subsequently, the gradient strength of this probe was calculated to be $4.979 \mathrm{G} \cdot \mathrm{mm}^{-1}$.

For the NMR samples of $\mathbf{2}, \mathbf{3}, \mathbf{4}\left[\mathbf{B} \mathbf{A} \mathbf{r F}^{\mathbf{2 4}}\right]$ and $\mathbf{5}\left[\mathbf{B A r F} \mathbf{F}^{24}\right]$ the $90^{\circ}{ }^{1} \mathrm{H}$ pulse length was exactly determined and the diffusion time $\Delta(\mathrm{d} 20)$ and the gradient length $\delta(\mathrm{p} 30)$ were optimized and are summarized in table $S 2$. The pseudo-2D experiments were performed with 8 scans in the direct dimension and 24 linear gradient ramp increments in the indirect dimension. Processing was done as $2 \mathrm{D}$ DOSY as well as using the $\mathrm{T}_{1} / \mathrm{T}_{2}$-relaxation module fitting the diffusion decays with the SimFit algorithm provided by the Bruker Software Package Topspin ${ }^{\text {TM }}$ 4.0.8 pl7.

Table S2. Summary of diffusion time $\Delta(\mathrm{d} 20)$ and gradient length $\delta(\mathrm{p} 30)$ for each ${ }^{1} \mathrm{H}$ NMR DOSY experiment.

\begin{tabular}{c|c|c|c|c}
\hline Entry & Compound & solvent & $\Delta(\mathbf{d} 20)[\mathbf{m s}]$ & $\boldsymbol{\delta}(\mathbf{p 3 0})[\mathbf{m s}]$ \\
\hline 1 & $\mathbf{2}$ & $\mathrm{CD}_{2} \mathrm{Cl}_{2}$ & 50 & 2.4 \\
2 & $\mathbf{4}\left[\mathbf{B A r F}^{24}\right]$ & $\mathrm{CD}_{2} \mathrm{Cl}_{2}$ & 60 & 2.6 \\
3 & $\mathbf{3}$ & $\mathrm{CD}_{2} \mathrm{Cl}_{2}$ & 50 & 2.0 \\
4 & $\mathbf{5}\left[\mathbf{B A r F}^{24}\right]$ & $\mathrm{CD}_{2} \mathrm{Cl}_{2}$ & 50 & 2.4 \\
5 & $\mathbf{2}$ & $\mathrm{THF}-d_{8}$ & 60 & 2.6 \\
6 & $\mathbf{4}\left[\mathbf{B A r F}^{24}\right]$ & $\mathrm{THF}-d_{8}$ & 60 & 2.6 \\
\hline
\end{tabular}

The average diffusion coefficients discussed in the main part were calculated by using only those signals for which the diffusion coefficients were not affected by resonances due to the $\mathrm{BArF}^{24}$ anion. This is the case when the signals of the bismepine-Tl adduct and the anion show chemical shifts that are too similar in the ${ }^{1} \mathrm{H}$ NMR spectrum (see Figure S5 and S6). 


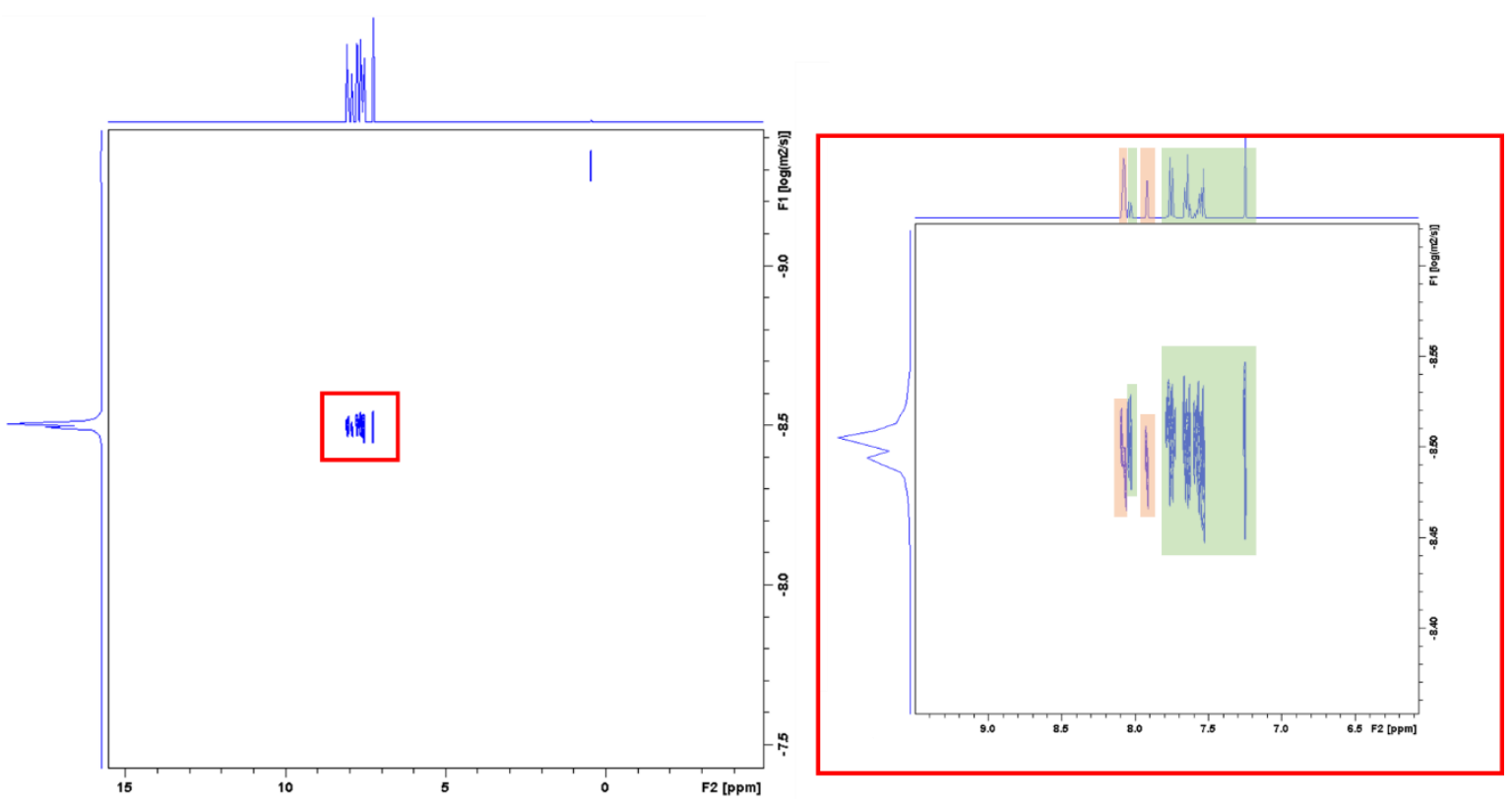

Figure S5. ${ }^{1} \mathrm{H}$ DOSY NMR spectrum of $4\left[\mathbf{B A r F}^{24}\right]$ in $\mathrm{CD}_{2} \mathrm{Cl}_{2}$ (left) and zoom-in on the region for aromatic protons (right). Resonances of the bismepine moiety are highlighted in green, resonances of the $\mathrm{BArF}^{24}$ anion are highlighted in red.

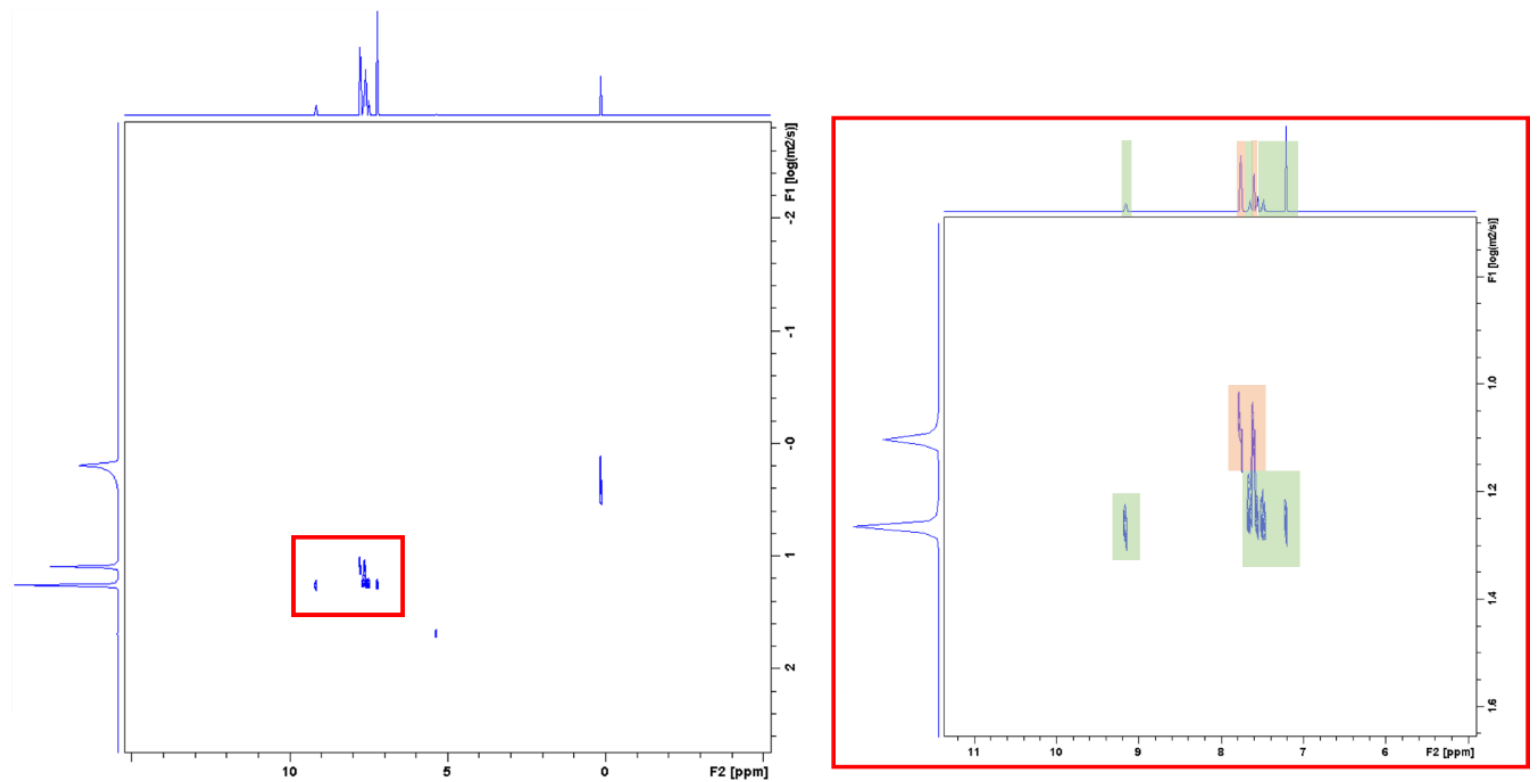

Figure S6. ${ }^{1} \mathrm{H}$ DOSY NMR spectrum of $\mathbf{5}\left[\mathbf{B} \mathbf{A r} \mathbf{F}^{\mathbf{2 4}}\right]$ in $\mathrm{CD}_{2} \mathrm{Cl}_{2}$ (left) and zoom-in on the region for aromatic protons (right). Resonances of the bismepine moiety are highlighted in green, resonances of the $\mathrm{BArF}^{24}$ anion are highlighted in red. 


\section{DFT Calculations}

DFT calculations were performed with the Gaussian program ${ }^{6}$ using the $6-31 \mathrm{G}(\mathrm{d}, \mathrm{p})^{7}(\mathrm{H}, \mathrm{C}, \mathrm{N}$, $\mathrm{P}$ ) or the LanL2DZ ${ }^{8-10}$ (As, Sb, I, Tl, Bi) basis set and the B3LYP functional. ${ }^{11}$ The D3 version of Grimme's dispersion model with the original D3 damping function was applied. ${ }^{12}$ Frequency analyses of the reported structures showed no imaginary frequencies for ground states. Thermodynamic parameters were calculated at a temperature of $298.15 \mathrm{~K}$ and a pressure of $1.00 \mathrm{~atm}$. NBO analyses were performed using the program version NBO $7 .{ }^{13}$

The thermodynamic parameters for the formation of arene adducts $\left[\left\{\mathrm{Pn}\left(\mathrm{C}_{14} \mathrm{H}_{10}\right) \mathrm{I}\right\}_{2} \mathrm{Tl}\right]$ were calculated and discussed in the main part $(\mathrm{Pn}=\mathrm{N}-\mathrm{Bi}$, see Table 2$)$. In order to determine the influence of dispersion forces, the thermodynamic parameters of this reaction were calculated without dispersion and compared with those in the main part (see Table S3.)

Table S3. Summary of thermodynamic parameters of the reaction shown in Table 1 in the main part. Thermodynamic parameters are calculated either with or without dispersion interactions.

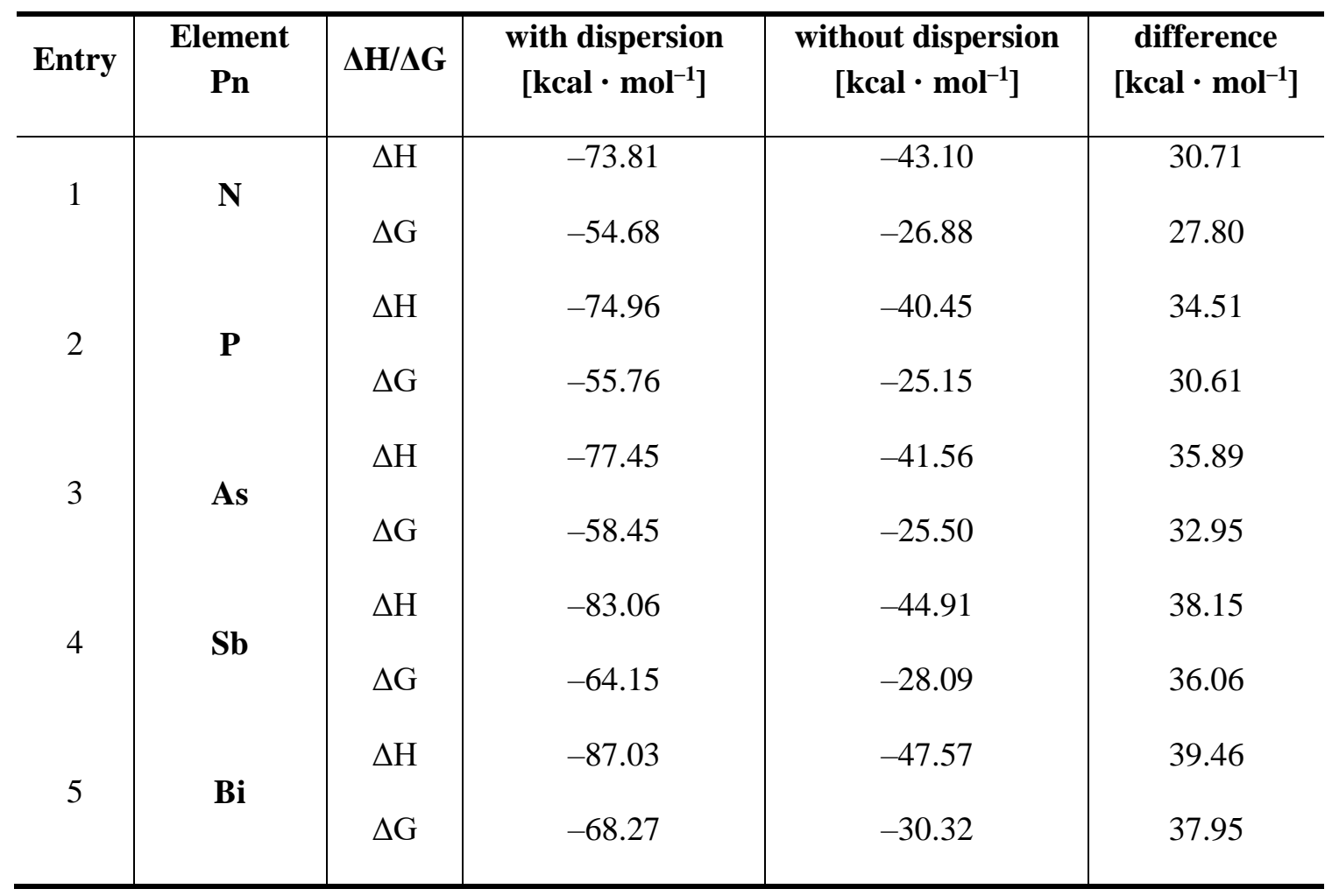

In all cases, the dispersion contributes to the stability of the compounds in the same order of magnitude, but with rising influence the heavier the element.

Deletion energies $\left(E_{d e l}\right)$ were calculated for compounds $\left[\left\{\mathrm{Pn}\left(\mathrm{C}_{14} \mathrm{H}_{10}\right) \mathrm{I}\right\}_{2} \mathrm{Tl}\right](\mathrm{Pn}=\mathrm{N}-\mathrm{Bi})$ and $\mathbf{4}^{+}-$ monomer (Table S4; $c f$. main part). All donor/acceptor interactions that are due to interactions between $\mathrm{C}-\mathrm{H}, \mathrm{C}-\mathrm{C}$ and $\mathrm{C}=\mathrm{C}$ bonds and the thallium cation were considered according to second order perturbation analyses. Only $\mathrm{C} \rightarrow \mathrm{Tl}$ interactions were taken into account. For $\mathbf{4}^{+}-$ monomer the deletion energies for each arene $\rightarrow \mathrm{Tl}$ interaction were calculated separately, as 
well as the olefin $\rightarrow \mathrm{Tl}$ interaction and are summarized in Table $\mathrm{S} 5$. Arene 1 represents the arene moiety of the dibenzobismepine unit with only one arene $\cdots$ Tl interaction, arene 2 and arene 3 belong to the second bismepine unit. The coordinating olefin is located in the ligand bridge.

Table S4. Calculated deletion energies $\left(E_{d e l}\right)$ for $\left[\left\{\mathrm{Pn}\left(\mathrm{C}_{14} \mathrm{H}_{10}\right) \mathrm{I}\right\}_{2} \mathrm{Tl}\right](\mathrm{Pn}=\mathrm{N}-\mathrm{Bi})$.

\begin{tabular}{c|c|c}
\hline Entry & Compound & $\boldsymbol{E}_{\text {del }}\left[\mathbf{k c a l} \cdot \mathbf{~ m o l}^{-\mathbf{1}}\right]$ \\
\hline 1 & {$\left[\left\{\mathrm{~N}\left(\mathrm{C}_{14} \mathrm{H}_{10}\right) \mathrm{I}\right\}_{2} \mathrm{Tl}\right]^{+}$} & 45.35 \\
2 & {$\left[\left\{\mathrm{P}\left(\mathrm{C}_{14} \mathrm{H}_{10}\right) \mathrm{I}\right\}_{2} \mathrm{Tl}\right]^{+}$} & 56.46 \\
3 & {$\left[\left\{\mathrm{As}\left(\mathrm{C}_{14} \mathrm{H}_{10}\right) \mathrm{I}\right\}_{2} \mathrm{Tl}\right]^{+}$} & 57.22 \\
4 & {$\left[\left\{\mathrm{Sb}\left(\mathrm{C}_{14} \mathrm{H}_{10}\right) \mathrm{I}\right\}_{2} \mathrm{Tl}\right]^{+}$} & 72.28 \\
5 & {$\left[\left\{\mathrm{Bi}\left(\mathrm{C}_{14} \mathrm{H}_{10}\right) \mathrm{I}\right\}_{2} \mathrm{Tl}\right]^{+}$} & 71.42 \\
6 & $4^{+}$-monomer & 53.19 \\
\hline
\end{tabular}

Table S5. Calculated deletion energies $\left(E_{d e l}\right)$ for each donor functionality in $\mathbf{4}^{+}$-monomer (for assignment of arene 1-3 and olefin see text).

\begin{tabular}{c|c|c}
\hline Entry & Donor moiety & $\boldsymbol{E}_{\text {del }}\left[\mathbf{k c a l} \cdot \mathbf{~ m o l}^{\mathbf{- 1}}\right.$ ] \\
\hline 1 & arene 1 & 15.76 \\
2 & arene 2 & 11.59 \\
3 & arene 3 & 10.81 \\
\hline 4 & olefin & 9.94 \\
\hline
\end{tabular}

The trend of $\mathrm{C}-\mathrm{Pn}-\mathrm{C}$ bond angles decreasing from $\mathrm{N}$ to $\mathrm{Bi}$ has been discussed in the literature and is also apparent from the parameters for compounds $\left[\mathrm{Pn}\left(\mathrm{C}_{14} \mathrm{H}_{10}\right) \mathrm{I}\right]$ shown in Table S6.

Table S6. C-Pn-C bond angles of geometry-optimized compounds $\left[\mathrm{Pn}\left(\mathrm{C}_{14} \mathrm{H}_{10}\right) \mathrm{X}\right]$.

\begin{tabular}{c|c|c}
\hline \multirow{2}{*}{ Pn } & \multicolumn{2}{|c}{ Bond angle C-Pn-C $\left[^{\circ}\right.$ ] } \\
\cline { 2 - 3 } & $\mathbf{X}=\mathbf{I}$ & $\mathbf{X}=\mathbf{M e}$ \\
\hline $\mathrm{N}$ & 117.32 & 118.14 \\
$\mathrm{P}$ & 98.32 & 99.59 \\
$\mathrm{As}$ & 95.15 & 95.71 \\
$\mathrm{Sb}$ & 91.41 & 91.58 \\
$\mathrm{Bi}$ & 89.75 & 89.89 \\
\hline
\end{tabular}




\section{Energies of Compounds Investigated by DFT Calculations}

The energies of compounds investigated by DFT calculations are given in Table S7. Their Cartesian coordinates are given in a separate .xyz file.

Table S7. Energies of calculated species. *: Species calculated without dispersion correction. SP: Results obtained from single-point calculations.

\begin{tabular}{|c|c|c|c|c|c|}
\hline$\#$ & Compound & $\Delta H$ [hartree] & $\Delta G[$ hartree $]$ & $E_{0}$ [hartree] & $\begin{array}{l}\text { Imaginary } \\
\text { frequencies }\end{array}$ \\
\hline 1 & $\mathbf{N}\left(\mathbf{C}_{14} \mathbf{H}_{10}\right) \mathbf{I}$ & -605.418999 & -605.472690 & -605.631742009 & none \\
\hline 2 & $\mathbf{P}\left(\mathbf{C}_{14} \mathbf{H}_{10}\right) \mathbf{I}$ & -892.072496 & -892.127853 & -892.282938561 & none \\
\hline 3 & $\operatorname{As}\left(\mathbf{C}_{14} \mathbf{H}_{10}\right) \mathbf{I}$ & -556.840703 & -556.897922 & -557.050523710 & none \\
\hline 4 & $\operatorname{Sb}\left(\mathbf{C}_{14} \mathbf{H}_{10}\right) \mathbf{I}$ & -556.128329 & -556.187013 & -556.337665638 & none \\
\hline 5 & $\mathrm{Bi}\left(\mathrm{C}_{\mathbf{1 4}} \mathrm{H}_{10}\right) \mathrm{I}$ & -556.176086 & -556.235956 & -556.385053325 & none \\
\hline 6 & $\mathbf{N}\left(\mathbf{C}_{14} \mathbf{H}_{10}\right) \mathbf{I}^{*}$ & -605.392283 & -605.445921 & -605.604904661 & none \\
\hline 7 & $\mathbf{P}\left(\mathbf{C}_{14} \mathbf{H}_{10}\right) \mathbf{I}^{*}$ & -892.045077 & -892.100505 & -892.255446174 & none \\
\hline 8 & $\operatorname{As}\left(\mathbf{C}_{14} \mathbf{H}_{10}\right) \mathbf{I}^{*}$ & -556.812695 & -556.870056 & -557.022420564 & none \\
\hline 9 & $\operatorname{Sb}\left(\mathbf{C}_{14} \mathbf{H}_{10}\right) I^{*}$ & -556.101980 & -556.160916 & -556.311195958 & none \\
\hline 10 & $\operatorname{Bi}\left(\mathbf{C}_{14} \mathbf{H}_{10}\right) I^{*}$ & -556.149512 & -556.209684 & -556.358359473 & none \\
\hline 11 & $\mathrm{~N}\left(\mathrm{C}_{14} \mathrm{H}_{10}\right) \mathrm{Me}$ & -633.954733 & -634.005271 & -634.207014043 & none \\
\hline 12 & $\mathbf{P}\left(\mathrm{C}_{14} \mathrm{H}_{10}\right) \mathrm{Me}$ & -920.568291 & -920.620846 & -920.815890585 & none \\
\hline 13 & $\operatorname{As}\left(\mathrm{C}_{14} \mathrm{H}_{10}\right) \mathrm{Me}$ & -585.312749 & -585.367201 & -585.559307506 & none \\
\hline 14 & $\operatorname{Sb}\left(\mathrm{C}_{14} \mathrm{H}_{10}\right) \mathrm{Me}$ & -584.585594 & -584.642002 & -584.830994885 & none \\
\hline 15 & $\mathrm{Bi}\left(\mathrm{C}_{14} \mathrm{H}_{10}\right) \mathrm{Me}$ & -584.623514 & -584.681375 & -584.868266834 & none \\
\hline 16 & $\mathbf{N}\left(\mathbf{C}_{14} \mathbf{H}_{10}\right) \mathbf{I}^{\mathbf{S P}}$ & --- & --- & -605.630428686 & --- \\
\hline 17 & $\mathbf{P}\left(\mathbf{C}_{14} \mathbf{H}_{10}\right) \mathbf{I}^{\mathrm{SP}}$ & --- & --- & -892.281832143 & --- \\
\hline 18 & $\operatorname{As}\left(\mathbf{C}_{14} \mathbf{H}_{10}\right) \mathbf{I}^{S P}$ & --- & --- & -557.049051989 & --- \\
\hline 19 & $\operatorname{Sb}\left(\mathbf{C}_{14} \mathbf{H}_{10}\right) I^{\mathrm{SP}}$ & --- & --- & -556.336033451 & --- \\
\hline 20 & $\operatorname{Bi}\left(\mathbf{C}_{14} \mathbf{H}_{10}\right) \mathbf{I}^{\mathrm{SP}}$ & --- & --- & -556.382560139 & --- \\
\hline 21 & $\mathbf{N}\left(\mathbf{C}_{14} \mathbf{H}_{10}\right) \mathbf{M e}^{\mathrm{SP}}$ & --- & --- & -634.205008983 & --- \\
\hline 22 & $\mathbf{P}\left(\mathrm{C}_{14} \mathrm{H}_{10}\right) \mathrm{Me}^{\mathrm{SP}}$ & --- & --- & -920.814450675 & --- \\
\hline
\end{tabular}




\begin{tabular}{|c|c|c|c|c|c|}
\hline 23 & $\operatorname{As}\left(\mathbf{C}_{14} \mathbf{H}_{10}\right) \mathrm{Me}^{\mathrm{SP}}$ & --- & --- & -585.558294917 & --- \\
\hline 24 & $\mathrm{Sb}\left(\mathrm{C}_{14} \mathrm{H}_{10}\right) \mathrm{Me}^{\mathrm{SP}}$ & --- & --- & -584.829684626 & --- \\
\hline 25 & $\mathrm{Bi}\left(\mathrm{C}_{14} \mathrm{H}_{10}\right) \mathrm{Me}^{\mathrm{SP}}$ & --- & --- & -584.866946760 & --- \\
\hline 26 & {$\left[\left\{\mathbf{N}\left(\mathbf{C}_{14} \mathbf{H}_{10}\right) \mathbf{I}\right\}_{2} \mathbf{T l}\right]^{+}$} & -1262.360410 & -1262.457199 & -1262.79142396 & none \\
\hline 27 & {$\left[\left\{\mathbf{P}\left(\mathbf{C}_{14} \mathbf{H}_{10}\right) \mathbf{I}\right\}_{2} \mathbf{T l}\right]^{+}$} & -1835.669233 & -1835.769229 & -1836.09521933 & none \\
\hline 28 & {$\left[\left\{\mathrm{As}\left(\mathrm{C}_{14} \mathbf{H}_{10}\right) \mathbf{I}\right\}_{2} \mathbf{T l}\right]^{+}$} & -1165.209666 & -1165.313655 & -1165.63438784 & none \\
\hline 29 & {$\left[\left\{\mathbf{S b}\left(\mathbf{C}_{14} \mathbf{H}_{10}\right) \mathbf{I}\right\}_{2} \mathbf{T l}\right]^{+}$} & -1163.793801 & -1163.900925 & -1164.21753597 & none \\
\hline 30 & {$\left[\left\{\mathbf{B i}\left(\mathbf{C}_{14} \mathbf{H}_{10}\right) \mathbf{I}\right\}_{2} \mathbf{T l}\right]^{+}$} & -1163.895638 & -1164.005378 & -1164.31866351 & none \\
\hline 31 & {$\left[\left\{\mathbf{N}\left(\mathbf{C}_{14} \mathbf{H}_{10}\right) \mathbf{I}\right\}_{2} \mathbf{T l}\right]^{+*}$} & -1262.258038 & -1262.359351 & -1262.68874594 & none \\
\hline 32 & {$\left[\left\{\mathbf{P}\left(\mathbf{C}_{14} \mathbf{H}_{10}\right) \mathbf{I}\right\}_{2} \mathbf{T l}\right]^{+*}$} & -1835.559395 & -1835.665780 & -1835.98509662 & none \\
\hline 33 & {$\left[\left\{\operatorname{As}\left(\mathbf{C}_{14} \mathbf{H}_{10}\right) \mathbf{I}\right\}_{2} \mathbf{T l}\right]^{+*}$} & -1165.096406 & -1165.205413 & -1165.52076203 & none \\
\hline 34 & {$\left[\left\{\operatorname{Sb}\left(\mathbf{C}_{14} \mathbf{H}_{10}\right) I\right\}_{2} \mathbf{T l}\right]^{+*}$} & -1163.680304 & -1163.791268 & -1164.10371578 & none \\
\hline 35 & {$\left[\left\{\mathrm{Bi}\left(\mathrm{C}_{14} \mathbf{H}_{10}\right) \mathbf{I}\right\}_{2} \mathrm{Tl}\right]^{+*}$} & -1163.779680 & -1163.892350 & -1164.20239497 & none \\
\hline 36 & {$\left[\left\{\mathbf{N}\left(\mathrm{C}_{14} \mathrm{H}_{10}\right) \mathbf{M e}\right\}_{2} \mathbf{T l}\right]^{+}$} & -1319.408902 & -1319.501200 & -1319.91897029 & none \\
\hline 37 & {$\left[\left\{\mathrm{P}\left(\mathrm{C}_{14} \mathrm{H}_{10}\right) \mathrm{Me}\right\}_{2} \mathrm{Tl}\right]^{+}$} & -1892.639202 & -1892.734269 & -1893.13974321 & none \\
\hline 38 & {$\left[\left\{\mathrm{As}\left(\mathrm{C}_{14} \mathrm{H}_{10}\right) \mathrm{Me}\right\}_{2} \mathrm{Tl}\right]^{+}$} & -1222.161556 & -1222.259570 & -1222.65997318 & none \\
\hline 39 & {$\left[\left\{\mathrm{Sb}\left(\mathrm{C}_{14} \mathrm{H}_{10}\right) \mathrm{Me}\right\}_{2} \mathrm{Tl}\right]^{+}$} & -1220.713802 & -1220.814560 & -1221.20997683 & none \\
\hline 40 & {$\left[\left\{\mathrm{Bi}\left(\mathrm{C}_{14} \mathrm{H}_{10}\right) \mathbf{M e}\right\}_{2} \mathrm{Tl}\right]^{+}$} & -1220.795557 & -1220.898712 & -1221.29049862 & none \\
\hline 41 & 2 & -1628.820580 & -1628.933296 & -1629.44005029 & none \\
\hline 42 & $4^{+}$-monomer & -1680.342662 & -1680.461145 & -1680.96596073 & none \\
\hline 43 & $2 *$ & -1680.196482 & -1680.317653 & -1629.34085195 & none \\
\hline 44 & $4^{+}$-monomer* & -1628.721956 & -1628.837575 & -1680.81882960 & none \\
\hline 45 & $\mathrm{Tl}^{+}$ & -51.40478100 & -51.42466900 & -51.4071413535 & none \\
\hline
\end{tabular}




\section{NMR Spectra of Isolated Compounds}
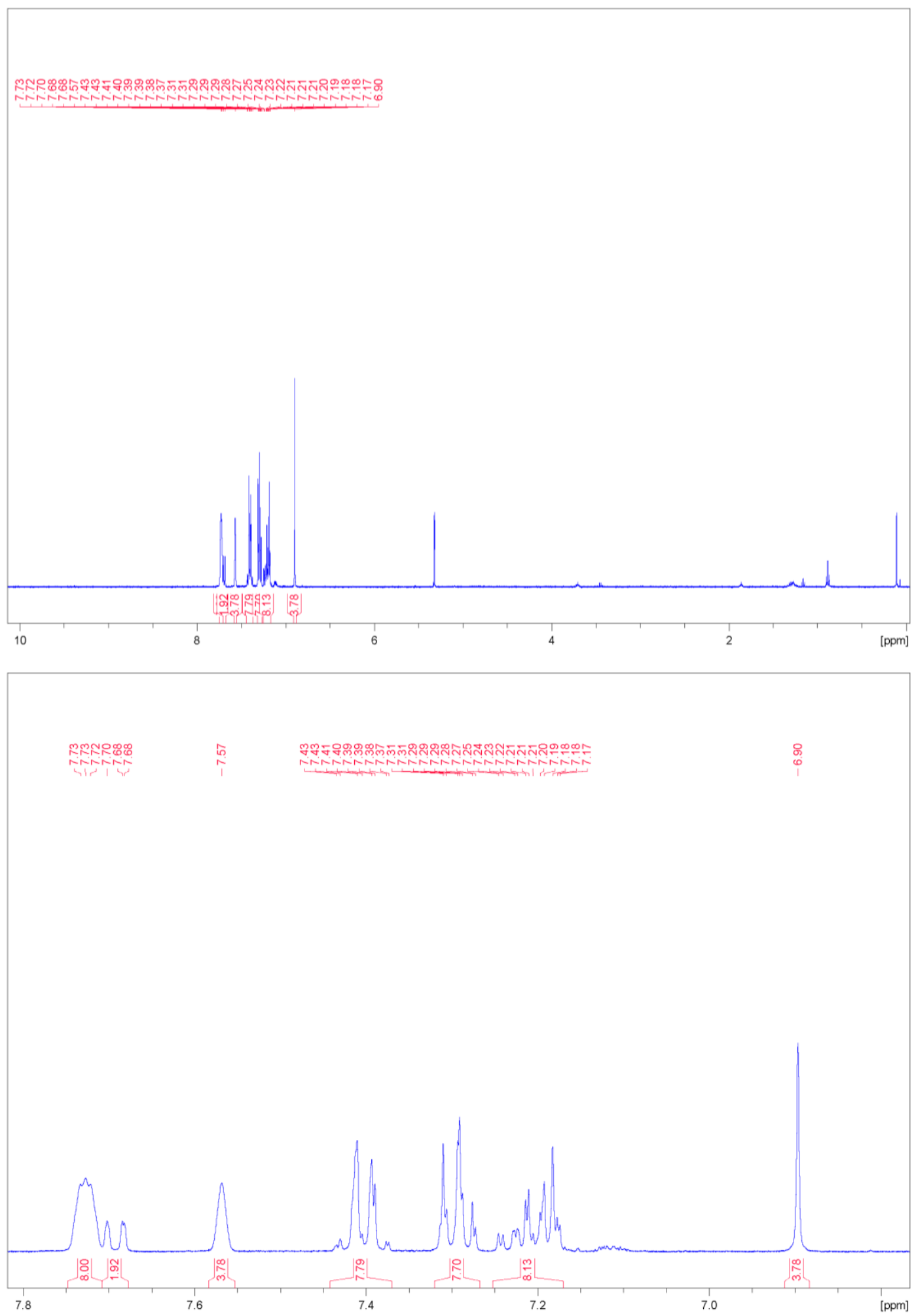

Figure S7. Top: ${ }^{1} \mathrm{H}$ NMR spectrum of $4\left[\mathbf{B A r F}^{24}\right]$ in $\mathrm{CD}_{2} \mathrm{Cl}_{2}$. Bottom: Aromatic region of the ${ }^{1} \mathrm{H}$ NMR spectrum of $\mathbf{4}\left[\mathbf{B} \mathbf{A r} \mathbf{F}^{\mathbf{2 4}}\right]$ in $\mathrm{CD}_{2} \mathrm{Cl}_{2}$. 

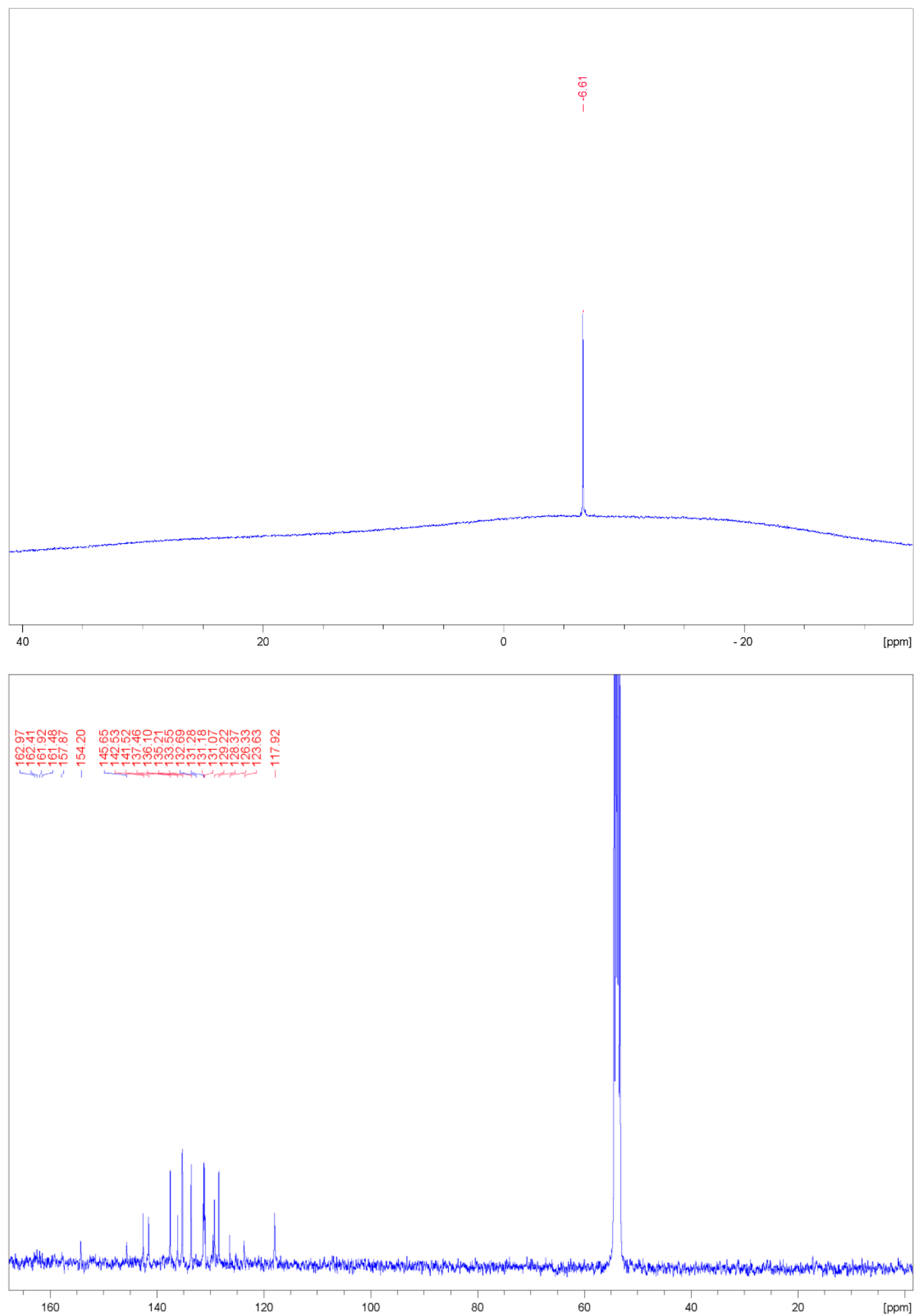

Figure S8. ${ }^{11} \mathrm{~B}$ and ${ }^{13} \mathrm{C}$ NMR spectra of $4\left[\mathbf{B A r F}^{24}\right]$ in $\mathrm{CD}_{2} \mathrm{Cl}_{2}$. 


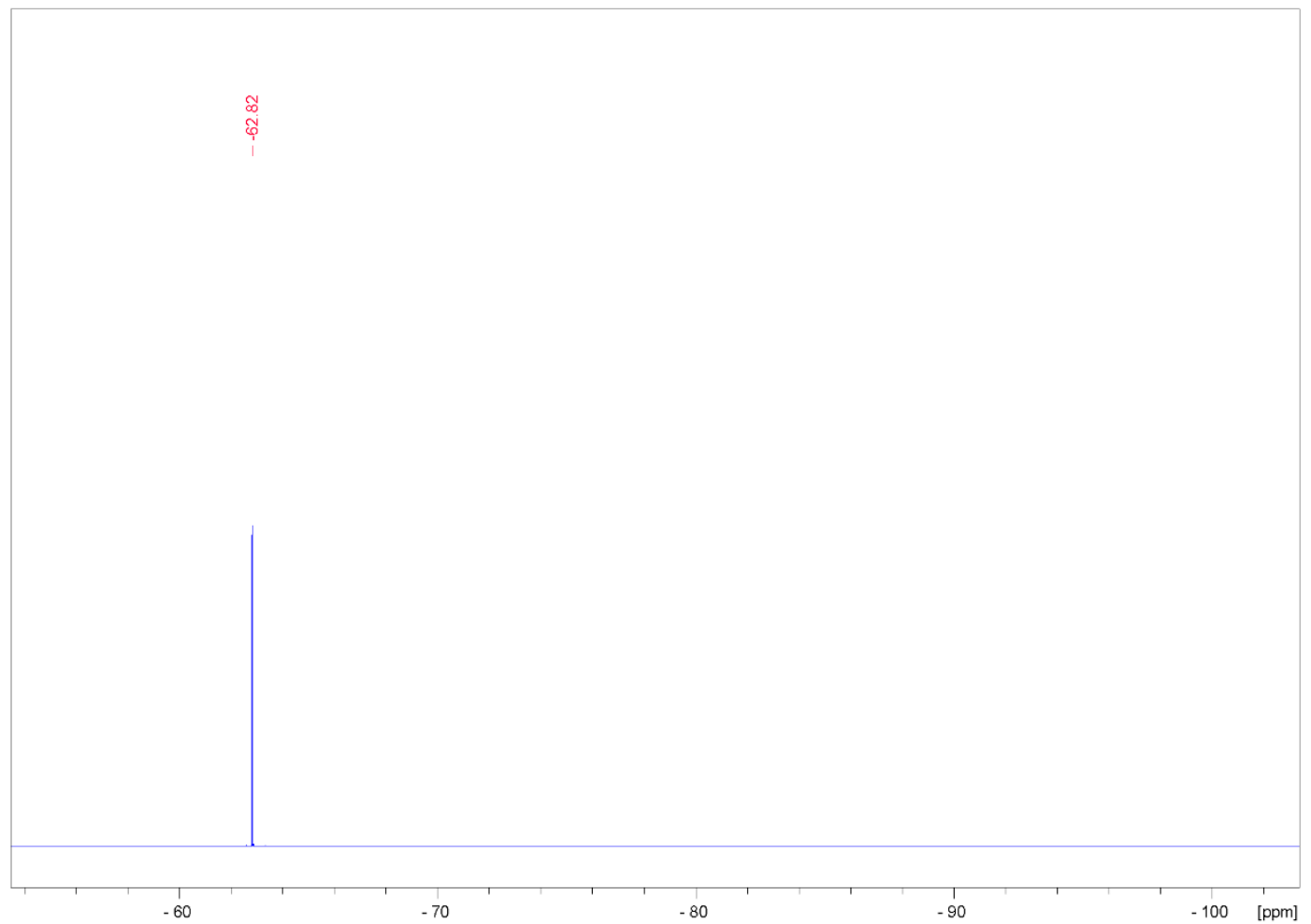

Figure S9. ${ }^{19} \mathrm{~F}$ NMR spectrum of $4\left[\mathbf{B A r F}^{\mathbf{2 4}}\right]$ in $\mathrm{CD}_{2} \mathrm{Cl}_{2}$. 

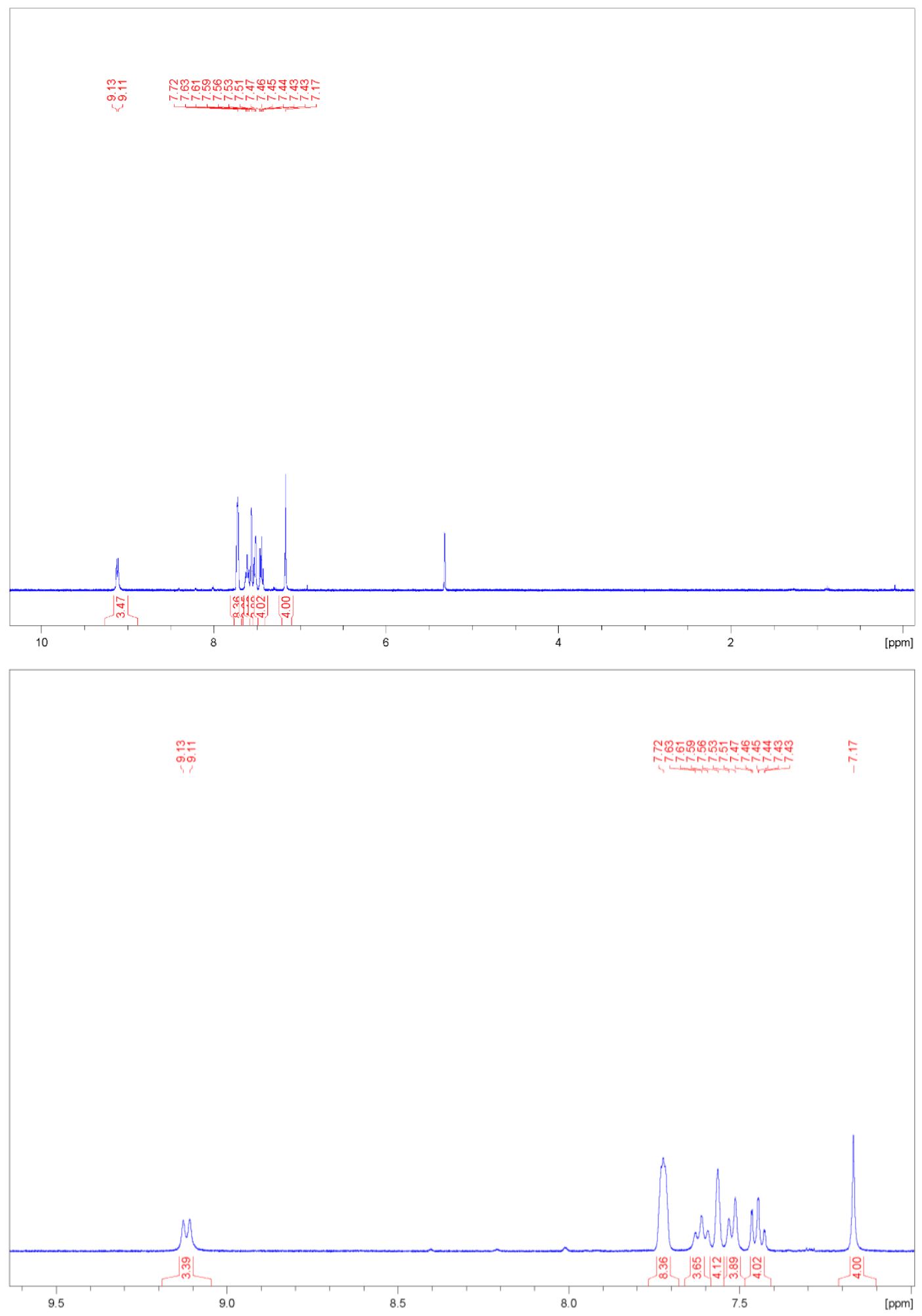

Figure S10. Top: ${ }^{1} \mathrm{H}$ NMR spectrum of $5\left[\mathbf{B A r F}^{24}\right]$ in $\mathrm{CD}_{2} \mathrm{Cl}_{2}$. Bottom: Aromatic region of the ${ }^{1} \mathrm{H}$ NMR spectrum of $\mathbf{5}\left[\mathbf{B} \mathbf{A r} \mathbf{F}^{24}\right]$ in $\mathrm{CD}_{2} \mathrm{Cl}_{2}$. 

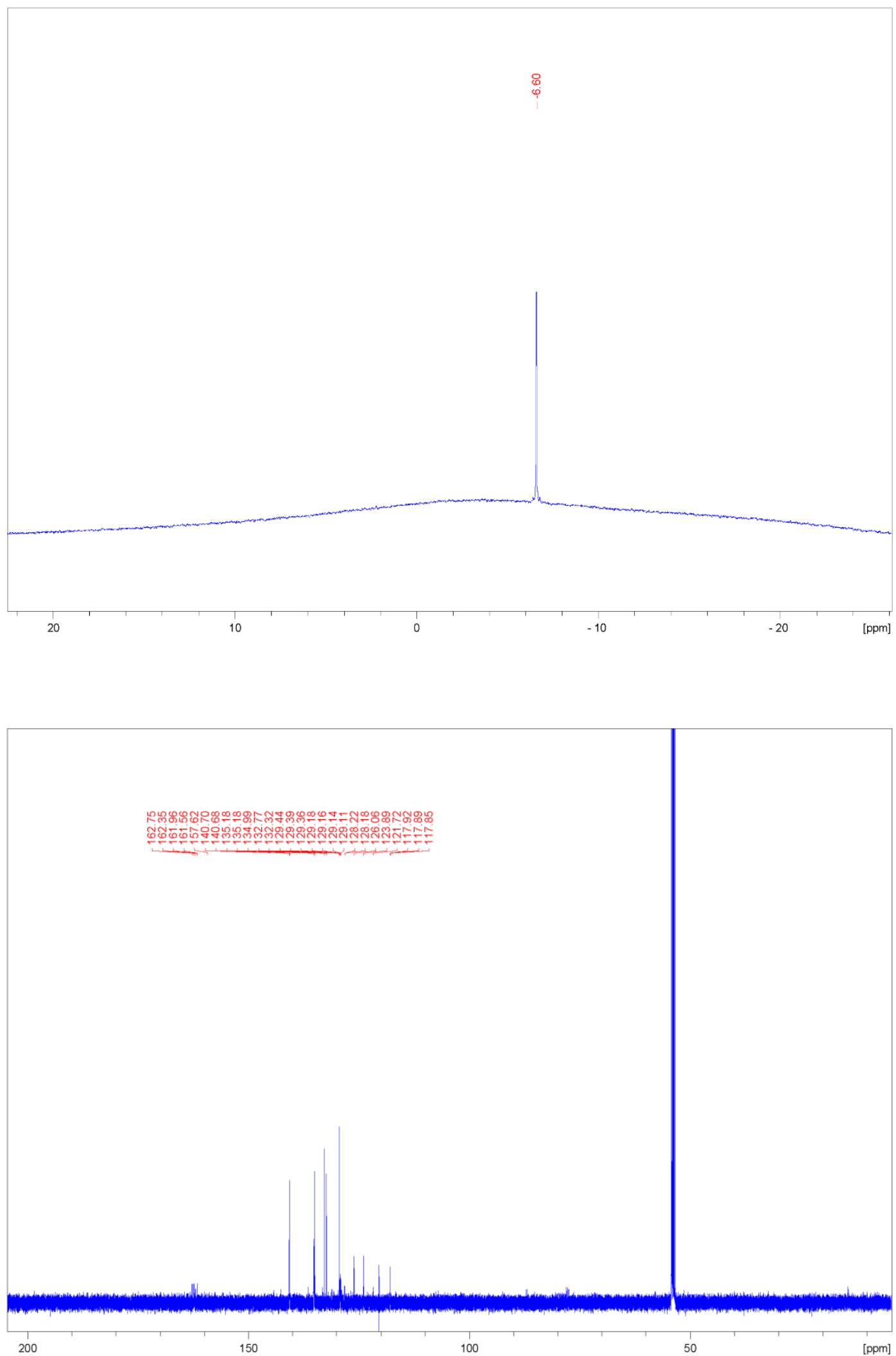

Figure S11. ${ }^{11} \mathrm{~B}$ and ${ }^{13} \mathrm{C}$ NMR spectra of $\mathbf{5}\left[\mathbf{B} \mathbf{A r} \mathbf{F}^{24}\right]$ in $\mathrm{CD}_{2} \mathrm{Cl}_{2}$. 


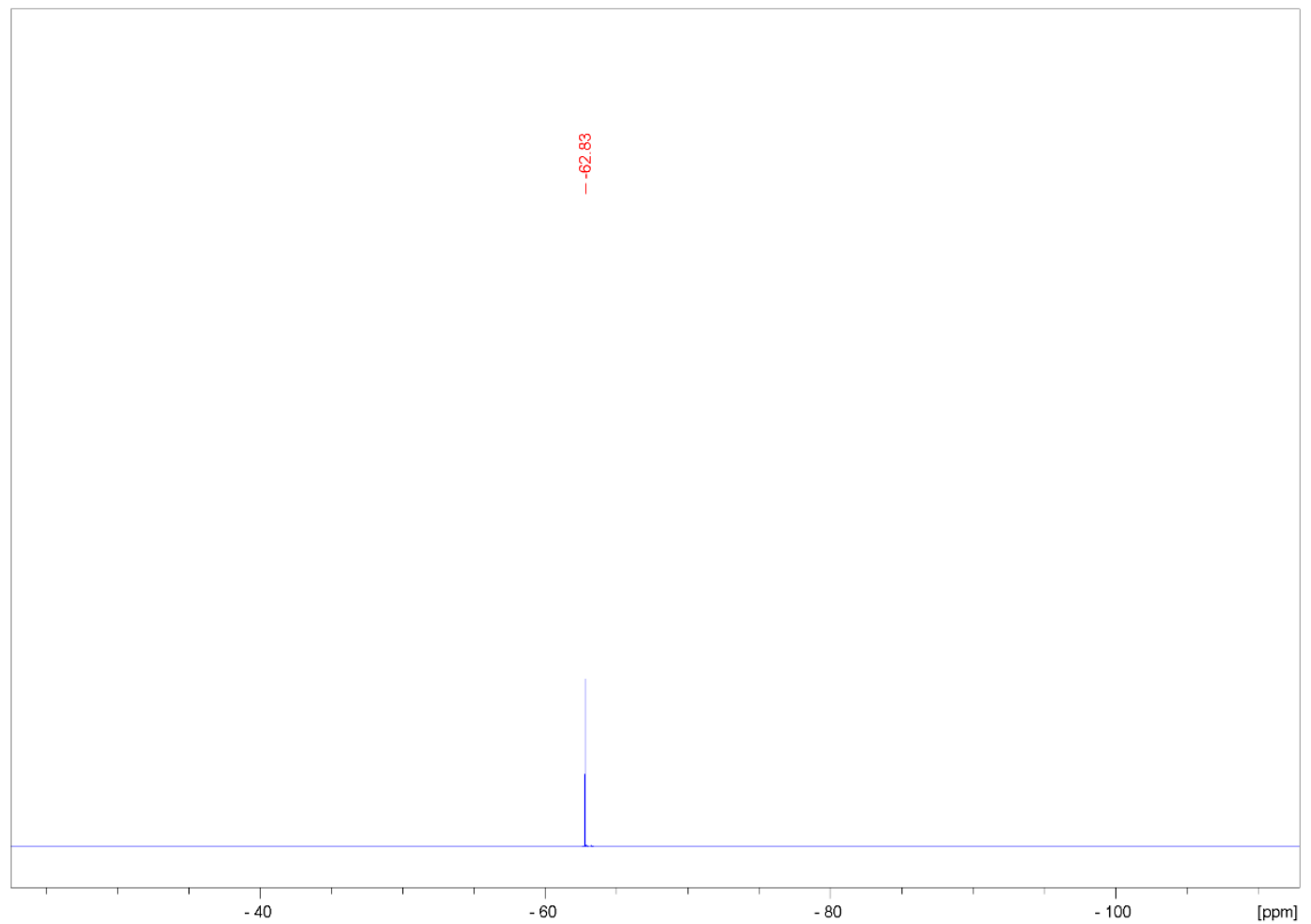

Figure S12. ${ }^{19} \mathrm{~F}$ NMR spectrum of $\mathbf{5}\left[\mathbf{B A r F}^{\mathbf{2 4}}\right]$ in $\mathrm{CD}_{2} \mathrm{Cl}_{2}$. 


\section{References}

(1) Sheldrick, G. M. A short history of lit SHELX. Acta Cryst. A 2008, 64, 112-122.

(2) Sheldrick, G. M. SHELXT: Integrating space group determination and structure solution. Acta Cryst. A 2014, 70, C1437.

(3) Sheldrick, G. M. SHELXT - Integrated space-group and crystal-structure determination. Acta Cryst. A 2015, 71, 3-8.

(4) Ramler, J.; Hofmann, K.; Lichtenberg, C. Neutral and Cationic Bismuth Compounds: Structure, Heteroaromaticity, and Lewis Acidity of Bismepines. Inorg. Chem. 2020, 59, 3367-3376.

(5) Berger, S.; Braun, S. 200 and more NMR experiments: A practical course, $1^{\text {st }}$ reprint; Wiley-VCH, 2011.

(6) Frisch, M. J.; Trucks, G. W.; Schlegel, H. B.; Scuseria, G. E.; Robb, M. A.; Cheeseman, J. R.; Scalmani, G.; Barone, V.; Petersson, G. A.; Nakatsuji, H.; Li, X.; Caricato, M.; Marenich, A. V.; Bloino, J.; Janesko, B. G.; Gomperts, R.; Mennucci, B.; Hratchian, H. P.; Ortiz, J. V.; Izmaylov, A. F.; Sonnenberg, J. L.; Williams; Ding, F.; Lipparini, F.; Egidi, F.; Goings, J.; Peng, B.; Petrone, A.; Henderson, T.; Ranasinghe, D.; Zakrzewski, V. G.; Gao, J.; Rega, N.; Zheng, G.; Liang, W.; Hada, M.; Ehara, M.; Toyota, K.; Fukuda, R.; Hasegawa, J.; Ishida, M.; Nakajima, T.; Honda, Y.; Kitao, O.; Nakai, H.; Vreven, T.; Throssell, K.; Montgomery Jr., J. A.; Peralta, J. E.; Ogliaro, F.; Bearpark, M. J.; Heyd, J. J.; Brothers, E. N.; Kudin, K. N.; Staroverov, V. N.; Keith, T. A.; Kobayashi, R.; Normand, J.; Raghavachari, K.; Rendell, A. P.; Burant, J. C.; Iyengar, S. S.; Tomasi, J.; Cossi, M.; Millam, J. M.; Klene, M.; Adamo, C.; Cammi, R.; Ochterski, J. W.; Martin, R. L.; Morokuma, K.; Farkas, O.; Foresman, J. B.; Fox, D. J. Gaussian 16, Revision B.01; Gaussian, Inc., 2016.

(7) Hariharan, P. C.; Pople, J. A. The influence of polarization functions on molecular orbital hydrogenation energies. Theoret. Chim. Acta 1973, 28, 213-222.

(8) Dunning, T. H.; Hay, P. J. Methods of electronic structure theory. In Modern theoretical chemistry; Plenum Press New York, 1977; $\mathrm{p} 1$.

(9) Hay, P. J.; Wadt, W. R. Ab initio effective core potentials for molecular calculations. Potentials for K to Au including the outermost core orbitals. J. Chem. Phys. 1985, 82, 299-310.

(10) Hay, P. J.; Wadt, W. R. Ab initio effective core potentials for molecular calculations. Potentials for the transition metal atoms Sc to Hg. J. Chem. Phys. 1985, 82, 270-283.

(11) Becke, A. D. Density-functional thermochemistry. III. The role of exact exchange. $J$. Chem. Phys. 1993, 98, 5648-5652.

(12) Grimme, S.; Antony, J.; Ehrlich, S.; Krieg, H. A consistent and accurate ab initio parametrization of density functional dispersion correction (DFT-D) for the 94 elements H-Pu. J. Chem. Phys. 2010, 132, 154104.

(13) E. D. Glendening; J. K. Badenhoop; A. E. Reed; J. E. Carpenter; J. A. Bohmann; C. M. Morales; P. Karafiloglou; C. R. Landis; F. Weinhold, University of Wisconsin, Madison, 2018. 